\title{
Global Economic Crisis: A View from South Africa
}

Patrick Bond ${ }^{1}$

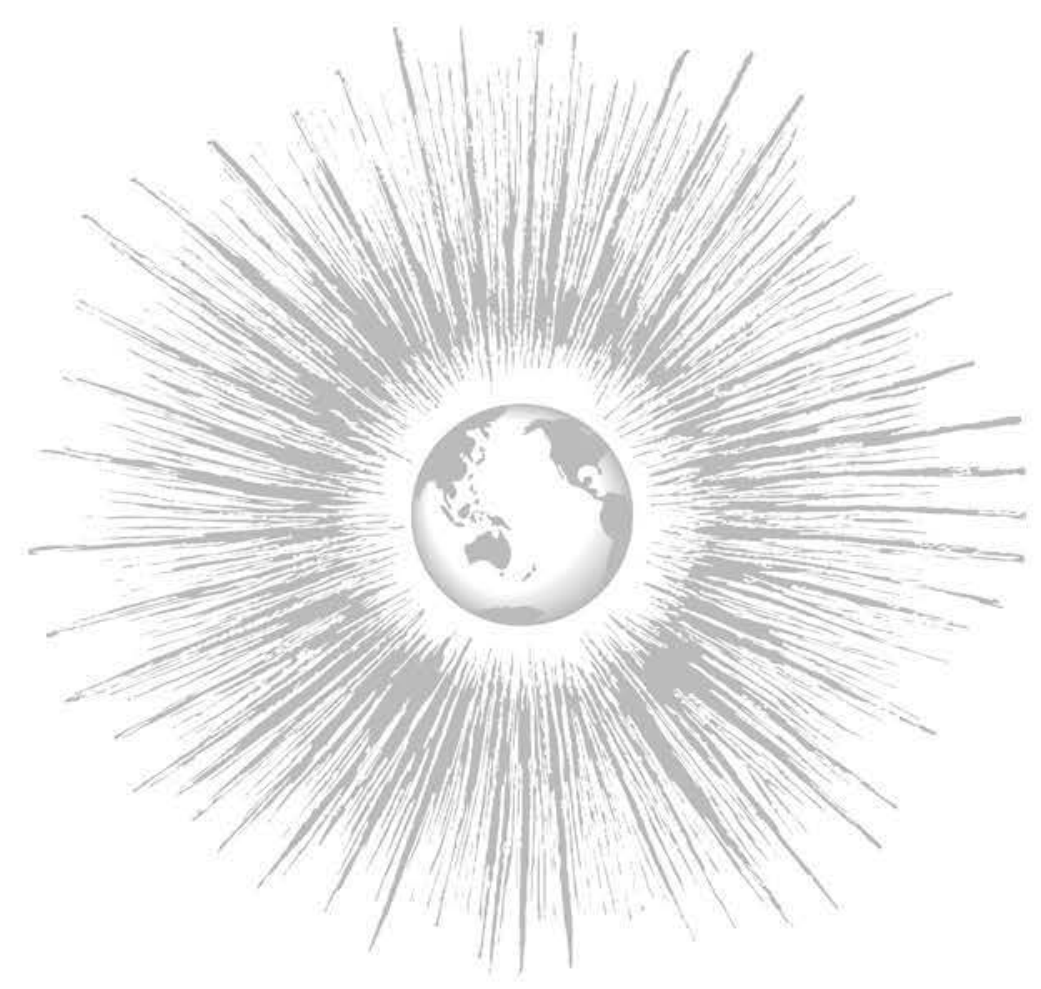

\section{INTRODUCTION: PRETORIA V, WASHINGTON?}

Any analysis of the erratic unfolding of global economic crisis is bound to be hotly contested. This is particularly so in mid-1999, amid claims from Washington that the past two years' dangers of financial meltdown and deflation were averted and finally extinguished through a combination of policy measures and good fortune: slightly looser Federal Reserve monetary policy adopted in September 1998, in the immediate wake of the successful public-private bailout of the Long Term Capital Management hedge fund; a new $\$ 90$ billion International Monetary Fund (IMF) insurance scheme announced the following month; the convening of key countries in a Forum on Financial Stability; the lack of financial contagion (contrary to expectations) in the wake of Brazil's January 1999 currency meltdown; the long-awaited revival (however infirm) of the Japanese economy; new plans for somewhat more transparent budgetary and exchange rate systems in emerging markets; and a decision at the G-8 Cologne meeting in June 1999 to sell $10 \%$ of the IMF's gold to fund partial debt relief for the poorest Third World countries. Indeed many observers were surprised at IMF Managing Director Michel Camdessus's success at turning the debt relief strategy into a vehicle for tougher "Enhanced Structural Adjustment Facility" conditions, just months after the IMF was criticised to the point of ridicule for its East Asian, Russian and Brazilian mishaps (effectively, granting $\$ 200$ billion in bad loans over 15 months, in exchange for the application of inappropriate austerity measures). To add insult to injury, an IMF plan to unite foreign bankers so as to avoid fracturing their power in forthcoming bankruptcy negotiations with sovereign states was unveiled to a select group on March 1, 1999, when Camdessus spoke-behind-the-scenes to an Institute of International Bankers meeting in Washington-of the parallel need for 
"creditor councils" which discipline "individual 'dissident' creditors" who catalyse "panic-stricken asset-destructive episodes" through too-zealous foreclosure actions. ${ }^{2}$

But, looking ahead from mid-1999, how convincing and durable are the multiple reassertions of financial power? Paired with an uneasy US geopolitical hegemony (in the wake of the superficially-successful NATO air war against Serbia) but considering the awesome overhangs in the US economy (trade and debt imbalances, consumer borrowing, stock market overvaluation, etc.), is it worth taking seriously the confidence regularly expressed in capitalism's flexible capacity to resolve perpetual crisis tendencies? In this context, too, what array of forces are now working systemically and antisystemically, and what is the likelihood of their success? Given the particularly virulent ways in which the crisis erupted in Mexico (early 1995), South Africa (early 1996 and mid-1998), Southeast Asia (1997-98), South Korea (early 1998), Russia (periodic but especially mid-1998) and Brazil and Ecuador (early 1999), are such semiperipheral sites good reflections of contradictions, contemporary social struggles, and potential resolutions?

To answer these questions requires thinking through a classic problem in world-systems analysis, the politics of scale. But to do so from a position of analytic strength, requires establishing a foundation for why deep-seated economic problems typically bubble up, in a spectacular, geographically uneven manner, into the world financial system every six or seven decades (Section 2); considering the array of different ideological and material positions in relation to the crisis, in particular five emerging reactions from different ideological camps (Section 3); and drawing strategic considerations from the structural analysis, while working through dilemmas now facing progressive social movements (and their strategists) over prospects for reforming global-scale institutions (Section 4).

There are many political economists, especially drawing from the worldsystems perspective, who consider with interest how capitalist processes play out in semiperipheral sites of either aggressive surplus value extraction or heightened socio-economic contradictions (including legitimation crises). This essay is located within debates in South Africa that are, perhaps surprisingly, relatively high on the agenda of ruling African National Congress (ANC) political elites. For if Nelson Mandela's first democratic South African government (1994-99) suffered, for example, at least half a million lost formal-sector jobs because it followed "sound" economic advice (proffered in part by Washington bureaucrats and promoted vigorously by financiers from New York, London, Zurich and Johannesburg), ${ }^{3}$ nevertheless, ANC leaders could by October 1998 openly state the obvious (in a paper issued alongside the SA Communist Party and Congress of South African Trade Unions-known collectively as the "Alliance"):

As the depth and relative durability of the crisis have become apparent, the dominant economic paradigm (the neoliberal "Washington Consensus") has fallen into increasing disrepute...The dominant assumption in the $1990 \mathrm{~s}$ has been that alignment with globalisation would guarantee economies more or less uninterrupted growth. The paradigm of an endlessly expanding global freeway, in which, to benefit, individual (and particularly developing) economies simply had to take the stand ard macroeconomic on-ramp (liberalisation, privatisation, deregulation, Alexibility and a 3 per cent budget deficit) is now in crisis. ${ }^{4}$

In another paper written by the oft-feted ANC Finance Minister, Trevor Manuel, presented at roughly the same time, a similar apparent break from orthodoxy was signaled:

It is interesting that at times like this $\mathrm{Mr}$. Keynes is again resurrected. There is a recognition that the standard prescription for macroeconomic stability and growth has not worked for everyone...As we attempt to find solutions a number of common themes are emerging; the need for capital regulation, improved supervision, greater transparency, reform of the Bretton Woods institutions, the need to shift away from the "Washington Consensus," to name a few. ${ }^{5}$

Also in October 1998, the leading ANC intellectual, Joel Netshitenzhe, complained bitterly in an official ANC discussion document - "The State, Property Relations and Social Transformation" - that South Africa was not attracting the foreign investment anticipated to correspond with the requisite "sound" economic policies.

If in the past the bourgeois state blatantly represented the interests of private capital, today its enslavement is even the more pronounced, with its policies and actions beholden to the whims of owners of stupendously large amounts of capital which is in constant flight across stocks, currencies and state boundaries. More often than not, governments even in the most advanced countries assert their role in the economy merely by "sending signals to the markets," which they can only second-guess. If in the past, the Bretton Woods Institutions (the IMF and World Bank) and the World Trade Organisation pursued 
the same interests as these powerful corporations and governments, today their prescriptions are turned on their heads as "the animal spirits" sway moods in a set of motions that have no apparent rhythm or logic.

Yet there is rhythm and logic. It is the logic of unbridled pursuit of profit which has little direct bearing to production ...

What this in fact means is that, in terms of the broad array of economic and social policy, information and even political integrity, the state has lost much of its national sovereignty. This applies more so to developing countries. While on the one hand they are called upon to starve and prettify themselves to compete on the "catwalk" of attracting limited amounts of foreign direct investment, they are on the other hand reduced to bulimia by the vagaries of an extremely impetuous and whimsical market suitor $!^{6}$

Frustration had clearly built up into an unprecedented rage against globalisation. The single most devastating evidence of how Washington (the US capital, in this case, not the Bretton Woods Institutions) favoured impetuous, whimsical market suitors in their unbridled pursuit of profit was the 1998-99 "full-court press" (as the State Department described its advocacy work) against South Africa for a 1997 Medicines Act that allowed the state to seek the cheapest world price for drugs (especially anti-virals to combat the country's debilitating AIDS crisis) through both "parallel importing" (a practice common in European Union pharmaceutical retailing) and "compulsory drugs licensing" - granting local producers rights to make copies of patented drugs without the approval of the patent holder (permissible in health emergencies under international law) - if they follow safeguards and pay a royalty to the patent owner ${ }^{7}$ In several meetings, US Vice President Al Gore twisted Thabo Mbeki's arm to withdraw the "offending language" in the Act.

But even if (as of mid-1999) Mbeki resisted pharmaceuticals-imperialism (and if his health officials spoke out strongly in the World Health Organisation against drug profiteering), South African government economic managers would still religiously maintain the two most important financial "fundamentals" - low inflation and a declining government budget deficit/GDP ratio-against quite sustained intra-Alliance pressure. ${ }^{8}$ There was no hint that Mbeki's government would turn from the Washington Consensus until there was a more profound shift in the balance of forces, a matter we must take up again later, while locating the $\mathrm{ANC}$ within the broader Third World nationalist resurrection of 1997-99.

However, amidst the increasingly hot thetoric, the most striking aspect of Alliance intellectuals' enquiry into these matters was, without doubt, their recourse to Marxian crisis theory, so it is to analysis of "overaccumulation" tendencies that we turn next.

\section{OVERACCUMULATION CRISIS}

How deep are the roots of the current economic problems? Are reforms to the "financial architecture" sufficient, or are the cracks right down in the very foundations of the system? Simply because the rhetorical devices deployed here are exceptionally unusual coming from this particular political tradition, consider the ANC-led Alliance answer in October 1998:

The present crisis is, in fact, a global capitalist crisis, rooted in a classical crisis of overaccumulation and declining profitability. Declining profitability has been a general feature of the most developed economies over the last 25 years. It is precisely declining profitability in the most advanced economies that has spurred the last quarter of a century of intensified globalisation. These trends have resulted in the greatly increased dominance (and exponential growth in the sheer quantity) of speculative finance capital, ranging uncontrolled over the globe in pursuit of higher returns...9

Tellingly, such analysis-inspired by the May-June 1998 New Left Review survey of the world economy by University of California historian Robert Brenner ${ }^{10}$ — was also endorsed in a March 1999 paper by the general secretary of the Korean Confederation of Trade Unions, Koh Young-joo:

The intensification of the fantastic and imperialistic neoliberal offensive and the economic crisis is the dual expression of one entity: the overaccumulation (overproduction) of capital since the 1970s. The global economy is characterised by overproduction and a decline in the rate of profit. Efforts of capital are concentrated on increasing the rate of profit, leading to greater monopolisation. And the global monopolies and their metropoles are intent on driving out state intervention in the process of reproduction. This is what is undertaken under the name of "deregulation."

Fur thermore, the decline in the rate of profit due to overproduction has meant that capital can no longer find sufficiently profitable areas for investment in production or distribution. This has forced capital to turn to speculation. The birth of mammoth speculative capital, fostered by the changes in global financial practices, has transformed the system into a "casino capitalism."11 
The semiperipheral turn to a marxian phraseology may not be unusual in historical perspective, but it is - as noted below - simultaneously jarring and refreshing given the reality of recent power relations. Nevertheless, the core line of argument is simple enough. As world-systems scholars have shown, the pattern of overaccumulation crisis, rising financial speculation and intensifying uneven development is grounded in empirical reality, and harks back, historically, to previous epochs. Illustrating the danger involved, historically, at least one third of all nation-states (not to mention corporations and consumers) fell into effective default during the 1820 s, 1870 s, 1930 s and 1980s-90s, following an unsustainable upswing of borrowing in the context of the crises of $1825-45,1872-92,1929-48$, and 1973-present. ${ }^{12}$ There are both global and national-scale manifestations of overaccumulation and financial crisis, though these play themselves out in terribly uneven ways, especially in the semiperiphery. ${ }^{13}$

How do we understand this problem, and in particular the question of why capital tends, as the Alliance put it, to overaccumulate ${ }^{214} \mathrm{~A}$ brief theoretical review may be in order in this section, so as to make the case that "reform" of global financial processes may not be sufficient.

To go back to basics, capital accumulation refers to the generation of wealth in the form of "capital." It is capital because it is employed by capitalists not to produce with specific social uses in mind, but instead to produce commodities for the purpose of exchange, for profit, and hence for the selfexpansion of capital. Such an emphasis by individual capitalists on continually expanding the "exchange-value" of output, with secondary concern for the social and physical limits of expansion (size of the market, environmental, political and labour problems, etc.), gives rise to enormous contradictions. These are built into the very laws of motion of the system.

Perhaps the most serious of capitalist self-contradictions, most thoroughly embedded within the capital accumulation process, is the general tendency towards an increased capital-labour ratio in production-more machines in relation to workers - which is fuelled by the combination of technological change and intercapitalist competition, and made possible by the concentration and centralisation of capital. Individual capitalists cannot afford to fall behind the industry norm, technologically, without risking their price or quality competitiveness such that their products are not sold. This situation creates a continual drive in capitalist firms towards the intro- duction of state-of-the-art production processes, especially labour-saving machinery. With intensified automation, the rate of profit tends to fall, and the reasons for this are worth reviewing. Profit correlates to "surplus value" which is only actually generated through the exploitation of labour in production.

Why is labour only paid a certain proportion of the value produced, with a surplus going to capital? Since capitalists cannot "cheat in exchange" - buy other inputs, especially machines that make other machines, from each other at a cost less than their value - the increases in value that are the prerequisite for production and exchange of commodities must emanate from workers. This simply means, in class terms, that capitalists do not and cannot systematically exploit other capitalists but they can systematically exploit workers. Here arises the central contradiction: with automation, the labour input becomes an ever-smaller component of the total inputs into production. And as the labour content diminishes, so too do the opportunities for exploitation, for surplus value extraction and for profits.

Given intensifying intercapitalist competition for profits - the basis of the Brenner thesis about the ongoing overaccumulation/falling-profits crisis-this situation exacerbates what becomes a self-perpetuating vicious spiral. Workers (as a whole) are increasingly unable to buy the results of their increased production. In turn this results in a still greater need for individual capitalists to cut costs. A given firm's excess profits are but only temporarily achieved through the productivity gains which automation typically provides, since every capitalist in a particular industry or branch of production is compelled to adopt state-of-the-art technologies just to maintain competitiveness. This leads to growth in productive capacity far beyond an expansion in what consumer markets can bear. (It is true that there are countervailing tendencies to this process, such as an increase in the turnover time of capital, automation, and work speed-up, as well as expansion of the credit system. But these rarely overwhelm the underlying dynamic for long, and there are limits to the height of the consumer debt pyramid.) The inexorable consequence, a continuously worsening problem under capitalism, is termed the overaccumulation of capital. Overaccumulation refers, simply, to a situation in which excessive investment has occurred and hence goods cannot be brought to market profitably, leaving capital to pile up in sectoral bottlenecks or speculative outlets without being put back into new 
productive investment. Other symptoms include unused plant and equipment; huge gluts of unsold commodities; an unusually large number of unemployed workers; and the inordinate rise of financial markets. When an economy reaches a decisive stage of overaccumulation, then it becomes difficult to bring together all these resources in a profitable way to meet social needs.

How does the system respond? There are many ways to move an overaccumulation crisis around through time and space. But the only real "solution" to overaccumulation - the only response to the crisis capable of reestablishing the conditions for a new round of accumulation - is widespread devaluation. Devaluation entails the scrapping of the economic deadwood, which takes forms as diverse as depressions, banking crashes, inflation, plant shutdowns, and, as Schumpeter called it, the sometimes "creative destruction" of physical and human capital (though sometimes the uncreative solution of war). The process of devaluation happens continuously, as outmoded machines and superfluous workers are made redundant, as waste (including state expenditure on armaments) becomes an acceptable form of mopping up overaccumulation, and as inflation eats away at buying power. This continual, incremental devaluation does not, however, mean capitalism has learned to equilibrate, thus avoiding more serious, system-threatening crises. Devaluation of a fully cathartic nature (of which the last Great Depression and World War are spectacular examples) is periodically required to destroy sufficient economic deadwood to permit a new process of accumulation to begin.

When overaccumulation becomes widespread, extreme forms of devaluation are invariably resisted (or deflected) by whatever local, regional, national or international alliances exist or are formed in specific areas under pressure. Hence overaccumulation has very important geographical and geopolitical implications in the uneven development of capitalism, as attempts are made to transfer the costs and burden of devaluation to different regions and nations or to push overaccumulated capital into the buildings (especially commercial real estate), infrastructure and other features of the "built environment" as a last-ditch speculative venture. Moreover, the implications of overaccumulation for balance in different sectors of the economy - between branches of production (mining, agriculture, manufacturing, finance, etc.), between consumers and producers, and between capital goods (the means of production) and consumer goods (whether luxuries or necessities) - can become ominous. Indeed, because the rhythm of overaccumulation varies across the economy, severe imbalances between the different sectors and "departments" of production (sometimes termed "disproportionalities" or "disarticulations") emerge and introduce threatening bottlenecks in the production and realisation of value, which further exacerbate the crisis.

These processes enhance the control and speculative functions of finance. The argument, simply, is that as overaccumulation begins to set in, as structural bottlenecks emerge, and as profit rates fall in the productive sectors of an economy, capitalists begin to shift their investable funds out of reinvestment in plant, equipment and labour power, and instead seek refuge in financial assets. To fulfil their new role as not only store of value but as investment outlet for overaccumulated capital, those financial assets must be increasingly capable of generating their own self-expansion, and also be protected (at least temporarily) against devaluation in the form of both financial crashes and inflation. Such emerging needs mean that financiers, who are after all competing against other profit-seeking capitalists for resources, induce a shift in the function of finance away from merely accommodating the circulation of capital through production, and increasingly towards both speculative and control functions. The speculative function attracts further flows of productive capital, and the control function expands to ensure the protection and the reproduction of financial markets. Where inflation may be a threat, the control functions of finance often result in high real interest rates and a reduction in the value of labour-power (and hence lower effective demand). Where bankruptcies threaten to spread as a result of overenthusiastic speculation, the control functions attempt to shift those costs elsewhere.

In sum, what we have sketched out above is a story of how crises are generated through the logical internal functioning of modern market economies, whether in national or global settings. A good amount of the world's systematic unevenness and inequality - not to mention its various geopolitical tensions - follows directly from the ebb and flow of capital, both geographically and from productive to financial circuits. This story fits present conditions extremely well, although this is not the place for a Brenner-style empirical demonstration of overaccumulation tendencies. ${ }^{15}$ Suffice to say that the key evidence required is that of devaluation - the collapse of several decades' worth of ordinary people's living standards in so many developing 
countries since the late 1970s, in Eastern Europe since the late 1980s, and in Emerging Markets since the mid 1990s - as felt particularly by workers, peasants, women, children, the elderly, indigenous groups and disabled people, as well as environments ${ }_{+}^{16}$

But if this is indeed where we have come from, what, then, are the key responses to the crisis? What reforms on the table offer what kinds of ways "out" of the crisis (or ways to defer and displace its pain)? If the crisis is indeed as deeply-rooted in the very logic of capitalism as the (marxian) theory suggests, what prospects are there for addressing the crisis at its roots, in a resurgence of popular anti-capitalism?

\section{THE CURRENT ARRAY OF FORCES.}

During 1997-99, varying positions emerged about the economic crisis from different material interests and economic ideologies. While it may today be possible to identify a few coherent positions, this may not be true in a few months or even weeks. In short, fluidity is the only constant. Nevertheless, we can throw caution to the wind by suggesting that as of mid-1999 five broad tendencies appear to have firmed up, representing systematic reactions to the global financial crisis. The five positions are, from left to right, what we can label a) the "New Social Movements"; b) "Third World Nationalism"; c) the "Post-Washington Consensus"; d) the "Washington Consensus"; and e) the "Old World Order" (see accompanying table at the end of the essay) [see Table 1].

The Washington Consensus. Consider, firstly, the most powerful: the status quo Washington Consensus, which still, in 1999, dogmatically promotes free trade, financial liberalisation and foreign investment incentives, business deregulation, low taxes, fiscal austerity and privatisation, high real interest rates, and flexible labour markets ${ }_{+}^{17}$ If there were problems outstanding in the world economy, they would always merely be temporary, according to the Consensus, to be overcome by more IMF bailouts (embarrassingly generous to New York bankers though they were), intensified application of 'sound' macroeconomic policies, augmented by greater transparency, a touch more financial sector supervision and regulation, and less Asian cronyism. (An early 1999 IMF attempt to go a bit further, to establish a Washington Consensus 'lender of last resort' was initially discredited, for it was seen as a naked power play.)

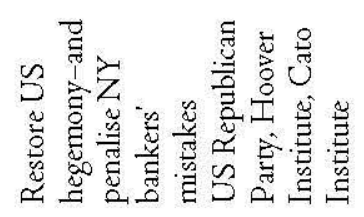

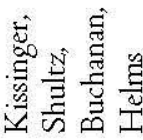
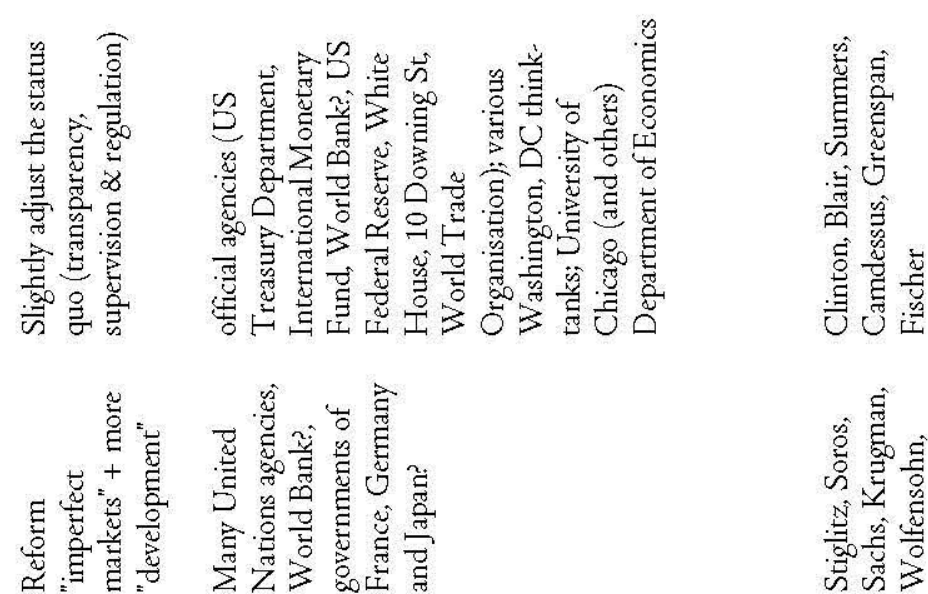

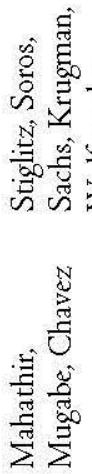
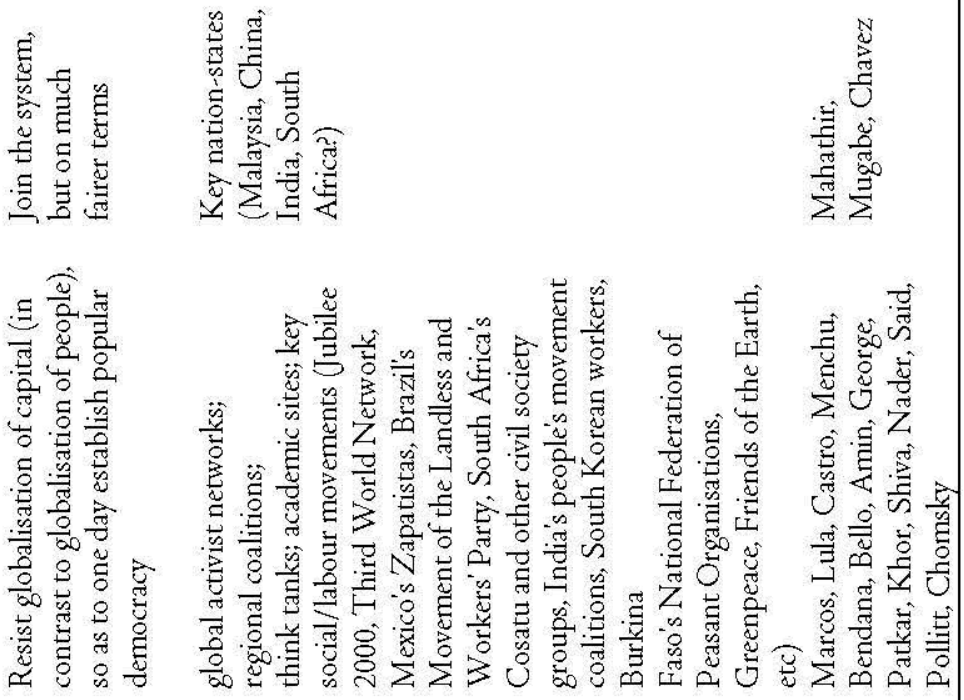
Providing political cover for the status quo at the end of the century were Bill Clinton and Tony Blair; providing operational support were US Treasury Secretary Robert Rubin and his deputy (and 1999 replacement) Lawrence Summers, US Federal Reserve chair Alan Greenspan, and IMF Managing Director Camdessus; and offering periodic intellectual justification were IMF Deputy MD Stanley Fischer and Summers. A variety of bank and corporate-sponsored Washington think-tanks echoed the party line, while outside the Washington Beltway, allies were found in the World Trade Organisation, Bank for International Settlements, OECD and numerous university economic departments. (At its core, the Washington Consensus is undergirded by a "Wall Street-Treasury Complex," in the words of Columbia University's Jagdish Bagwati; and indeed as another world-famous conservative economist, Rudiger Dornbusch, conceded in 1998, "The IMF is a toy of the United States to pursue its economic policy offshore") ${ }^{18}$

The Old World Order. Secondly, amongst those scornful of the Consensus were conservatives, largely based in reactionary pockets of the United States. But it was a mistake to discount US politicians like Jesse Helms, Trent Lott, Pat Buchanan and their ilk as mere populist rednecks. Their critique of public bailouts for New York bankers was backed by think-tanks (like the stalwart-conservative Heritage Foundation and the libertarian but surprisingly influential Cato Institute in Washington) and closely paralleled by elite conservative concerns - notably of Henry Kissinger and George Shultz, geopoliticians who lost dear friends like Suharto in the 1997-98 financial turmoil — which together led by 1998 to both a formidable attack on IMF policies as unworkable, and opposition to the US Treasury Department's request for $\$ 18$ billion in further IMF funding. ${ }^{19}$ The most interesting problem for Washington analysts is deciphering the occasional tactical alliances between a Pat Buchanan, say, and left-populist movements, such as the Ralph Nader networks and Friends of the Earth. ${ }^{20}$ Political strategies that unite right and left, as inter-war Germany showed, do most damage to the latter, a point we will return to. While the right-wing challenge appears formidable at times, it is also subject to cooptation, as occurred in October 1998 when Bill Clinton bought off Republican opposition by doing a deal which will make IMF conditionality even more fierce, by shortening repayment periods and raising interest rates on future bailout loans. Xenophobia and isolationism are logical political threats from this current, and economically it wouldn't be hard to envisage latter-day Smoot-Hawley-style protective tariffs kicking off a downward spiral of trade degeneration reminiscent of the early 1930s, if Old World Order advocates have their way.

The Post-Washington Consensus. Thirdly, there appears an emerging reform position-yet often taking one step forward, then two back - that we can term the "Post-Washington Consensus" in honour of World Bank chief economist Joseph Stiglitz. ${ }^{21}$ Aimed at perfecting the capitalist system's "imperfect markets," Stiglitz cites organic problems like asymmetric information in market transactions (especially finance) and anti-competitive firm behaviour as key contributors to the present instability. Likewise speculator George Soros has attributed financial volatility to bankers' herd instincts ${ }_{+}{ }^{22}$ However, by advocating somewhat more substantive national regulatory interventions (tougher anti-trust measures, and even speed bumps or dual exchange rates to slow hot money) and more attention to social development and employment, Stiglitz is as reluctant to tamper with underlying dynamics as is Soros, whose call for a global banking insurance fund looks suspiciously self-interested (particularly coming at a time, in August 1998, when he lost several billion dollars of his Russian investments due to Boris Yeltsin's default on state debt) ${ }_{{ }^{23}}$

Unexpectedly, perhaps, a local South African variant of Soros was Donald Gordon, the Liberty Life insurance magnate. After losing enormously to speculators running away from his $\$ 350$ million "euro-convertible bond" issue (in the process crashing Liberty's share value), Gordon remarked ruefully in 1999,"In the name of short-term gain for a few, these people have been allowed to undermine most of the emerging markets. In South Africa [foreign traders' speculation on local assets] was the financial equivalent of allowing hostile war boats free rein along our coast. It is a destructive activity that undermines the very core of our sovereignty." As his interviewer interpreted,

Gordon reckons it [the eurobond] opened a Pandora's box of arbitrage activity that attacked the very substance of Liberty for four years. It marked the beginning of a period that saw stock lending, asset swaps and derivative trading take off on a grand scale, activities which seemed predicated on the devaluation of liquid blue chip stocks. Four years on and having devoted much energy and four annual reviews to the problem, Gordon remains perplexed 
by the previous unwillingness of global authorities to rein in the destructive powers of arbitrageurs. ${ }^{24}$

Others from a neoliberal economic background who are jumping the Washington Consensus ship include Massachusetts Institute of Technology economist Paul Krugman, who claims both a temporary fondness for capital controls to halt speculative runs, and responsibility for Mahathir Mohamad's September 1998 restrictions on trading the Malaysian ringgit ${ }_{+}^{25}$ Likewise, Jeffrey Sachs, director of the Harvard Institute for International Development, offers critiques of IMF austerity-economics so vociferous as to nearly disguise his own previous advocacy of deregulatory shock therapy from Latin America to Eastern Europe. ${ }^{26}$

More durable than the growing chorus of reform-oriented neoliberals are the institutions which have an actual material stake in promoting human welfare, such as several key United Nations agencies (whether they succeed or not is another matter) ${ }_{{ }^{27}}$ More confusing than any of the other reformers is the World Bank, whose President James Wolfensohn allows Stiglitz space to attack the IMF but whose own unoriginal contribution to the debate-a January 1999 paper on the Bank's "new paradigm" reminiscent of modernisation theory - describes his institution's function as the opposite side of the same coin of the IMF, one doing macroeconomic "stabilisation," the other "development." ${ }^{28}$ More potentially significant than any of the above are the shifting political sands of social-democratic (and Green or otherwise leftleaning) party politics in Germany, France, Italy and Japan. But the March 1999 departure of Oskar Lafontaine represents a profound setback for this current and realigns Germany away from France (at least Jospin's wing of Socialism) and towards Britain, matching the failure of the Japanese (led by Miyazawa) to establish an Asian Monetary Fund, as a result of a Rubin/ Summers veto ${ }^{29}$ More and more, the presence of Keynesian-oriented officials from Tokyo and Paris would benefit from the mid-1999 realisation that state fiscal stimulation actually produced, finally, some results in Japan. Moreover, especially given its importance to the South African debate, the Stiglitz "information-theoretic" approach to economics (and the role of Stiglitz himself) should be revisited again a bit later.

Third World Nationalism. Fourthly, the equivalent group in the Third World Nationalist camp cannot claim to share traditions in any respect. While China and India are forthrightly resisting financial liberalisation and Russia formally defaulted in August 1998 (if only temporarily-but in the process avoided seizure of assets by creditors), it is in rather different nationalist regimes in Asia, Africa and Latin America that we can identify more radical discourses of opposition to the Washington Consensus. From Malaysia (Mahathir) to Zimbabwe (Robert Mugabe) to Venezuela (Hugo Chavez), IMF-bashing is back in style, even if the rhetorical flourishes have different origins (one Muslim, one self-described socialist, one simply populist). Yet self-evidently, the trajectory chosen in these three cases, amounts, at best, to attempting to join the system, to play by its rules and, having discovered that the game is set up unfairly, to adjust these rules somewhat in the Third World's favour ${ }^{30}$ More typical of a tamed nationalism was the offhand remark by Nelson Mandela at the July 1998 Mercosur meetings of South American nations, that "Globalisation is a phenomenon that we cannot deny. All we can do is accept it."

Not even reflective of the 1970 s call for a New International Economic Order, this strain faded badly over the subsequent two decades. Most leaders and political parties of Second and Third World societies who at one point (at least momentarily) carried the aspirations of a mass-popular electorate ${ }^{32}$ rapidly reversed allegiance, imposing ineffectual and terribly unpopular structural adjustment programmes. In the cases of Mahathir, Mugabe and others, "talking left" also entailed repression of public interest groups and trade unions (and women and gay rights movements), which was less publicised in 1998-99 but just as chilling to democratic processes as the arrests of a high-ranking Malaysian politician (of the Washington Consensus ideological ilk) and of several Zimbabwean journalists.

Not just a problem of Third World nationalism, selling out the poor and working classes on behalf of international finance was also the general fate of so many labour and social democratic parties in Western Europe, Canada and Australia. Even where once-revolutionary parties remained in control of the nation-state-China, Vietnam, Angola, and Mozambique, for instance - ideologies wandered over to hard, raw capitalism. And yet, too, the very universality of financial crisis would necessarily allow counterhegemonic voices to emerge.

Thus there was still talk within the ANC of potential interlocking interests of major Southern Hemisphere nations, which would potentially reflect renewed muscle in the Non-Aligned Movement, Group of 77 and 
various other fora of revived nationalisms. Such cooperation is not without foundation-for example, the October 1998 Alliance document explicitly asked, "Can we forge a Brasilia-Pretoria-Delhi-Beijing Consensus in the absence of any Washington Consensus?" (though cynics would rebut that if the global establishment looked fragmented at that point, so too did Brazil's crisis-ridden liberal-corporate regime, the ANC's neoliberal proto-Africanism, Hindu nationalism and Chinese bureaucratic-Communism-cum-rampant-capitalism)., ${ }^{33}$ That the South African government, during 1998-99, occupied a host of crucial positions-head of the Non-Aligned Movement, president of UNCTAD, head of the Commonwealth, head of the Organisation of African Unity, host of the Southern African Development Community, UN Security Council member, holder of a director position at the IMF and World Bank-meant that while ANC economic policy was without question still loyal to the Washington Consensus, nevertheless the kinds of questions raised by South African political leaders were potentially very important for change in the wider world.

New Social Movements. Which brings us, fifthly, to the New Social Movements (a phrase chosen for convenience, not to imply a particular political tilt), whose goal typically was to promote the globalisation of people and balt or at minimum radically modify the globalisation of capital. ${ }^{34}$ These movements spanned Old Left forces (many labour movements, and some ex-Stalinist Communist Parties), ${ }^{35}$ other newer political parties, ${ }^{36}$ progressive churches, human rights and disarmament movements, democracy activists, urban/ rural community and indigenous peoples movements, organisations of women, youth and the elderly, HIV and health activists, disability rights lobbyists, consumer advocates, and environmentalists who work from the local to the global scales (Greenpeace and Friends of the Earth in the latter group, along with international environmental justice networks).

Naturally, these movements are all extremely diverse in all aspects of their existence. Were there any discourses that could combine the massbased movements and the NGOs, the proletarian (or often lumpen) activists and petit-bourgeois intellectuals, the women and the men, the environmentalists and the workers? In both strategic and tactical respects, achieving a synthesis of "militant particularist" struggles is always difficult, not least in the simple matter of movement leaders and activists even finding common and mutually-supportive discourses ${ }_{+}^{37}$ Nevertheless, virtually all countries provided evidence, by the turn of the century, of coalitions and networks of anti-globalisation activists, many of which were fairly well-grounded in mass democratic organisations that acted locally but thought globally. ${ }^{38}$

Some localised efforts were already having inspiring results by the turn of the century, such as anti-dam struggles in parts of South Asia and the unveiling of Chile's repressive legacy as part of an international campaign to bring General Pinochet to justice. But it was always vital to question whether these sorts of organisations could forge links, so as to not only think globally and act locally, but also act globally? ${ }^{39}$ The most successful of these groups during the late 1990s tackled three global issues: landmines (nearly victorious were it not for the United States), the Multilateral Agreement on Investment (where several stunning stalemates were won mainly in European settings) and the Third World debt. Indeed it was possible to locate within the "Jubilee 2000" debt cancellation movement (particularly its Asian, African and Latin American components) an extremely effective campaigning spirit that not only attracted the likes of celebrities Muhammed Ali and U2 singer Bono, but also drew tens of thousands of activists to protest at G-8 meetings in Birmingham in 1998 and Cologne in 1999.40

Not only did social movements show that in some settings they could move from marginal sideline protest to shake ruling-class confidence in major neoliberal initiatives (the North American Free Trade Agreement and US support for the General Agreement on Tariffs and Trade were threatened more by radical US farmer and labour activists, than by the Republican right-populists). They also claimed quite substantial resources for future struggles, including effective advocacy networks ${ }^{41}$ and a few progressive nerve centres in sites of power, particularly Washington, DC.42 There were, in addition, several radical economic think-tanks associated with the social movements, ${ }^{43}$ university allies ${ }^{44}$ and a handful of accessible international activist-oriented periodicals ${ }^{45}$ and publishing houses, ${ }^{46}$ not to mention world-class spokespeople and luminaries from the new movements' who easily outwit conservative debating partners ${ }^{47}$

The global balance of forces, to be sure, is very clearly weighted against Third World Nationalists and New Social Movements, and there appears little real basis for any forms of alliance between the two given the former's penchant for authoritarianism and patriarchy. There are also a variety of other important, organised social forces (such as Muslim fundamentalist 
oppositionists, Andean guerrillas or still-stodgy US trade unionists) which don't neatly fit into any camp as yet and which may influence matters to some degree. In addition, the global crisis resurrected platforms for wellmeaning economist-technocrats reformers who did not easily fit into any of the camps noted above. ${ }^{48}$

Amongst the New Social Movements there are two fault-lines. One is a terribly dangerous tendency amongst the more conservative (and often "inside-the-Beltway") NGOs and environmental groups-some even derisively called Co-opted NGOs, or "CoNGOs" - to cut pragmatic yet ultimately absurd, untenable deals with the establishment (endorsements of the US-Africa "Growth and Opportunity" free trade deal, or numerous negotiations over the environment) ${ }_{4}^{49}$ 'The other is an ongoing debate over whether energy should be invested in helping Post-Washington Consensus reforms constitute a global state regulatory capacity - expanding upon embryos like the IMF and Bank, WTO, United Nations and Bank for International Settlements - or whether in contrast the immediate task should be defunding and denuding of legitimacy the current sites of potential international regulation so as to reconstitute a progressive politics at the national scale. This latter problem we can now address in detail.

\section{SCALES OF POLITICAL REFORM.}

In June 1999, John Kenneth Galbraith advised an audience at the London School of Economics, "When you hear it being said that we've entered a new era of permanent prosperity with prices of financial instruments reflecting that happy fact, you should take cover. Let us not assume that the age of slump, recession, depression is past. ${ }^{{ }^{50}}$ But as noted at the outset of this essay, many do just that, supported by emollient proclamations from sites of international financial power. After a year of sweating through discrete but severe hazards (the Russian default, hiccups on Wall Street, Malaysian capital controls, Long Term Capital Management's bankruptcy, Brazilian and Ecuadorean curtency meltdowns), G-7 leaders who met in Cologne the same month were cocky about the restoration of global economic stability and growth. If they are right, the steady construction of a world state can continue apace without opponents' legitimate recourse to the 1997-99 critique shared by forces as diverse as mass-popular movements and George Soros: global financial architects (who in fact aim not to build anything anew, but to redecorate) are incompetent.

It is therefore worth beginning a discussion of scale politics by defending the assertion that the reforms proposed by the Washington Consensus and Post-Washington Consensus are inadequate. Because together they identify the global crisis as emanating from lack of information and accountability, or from corruption or ill-regulated financial markets, the policy recommendations of both Washington and Post-Washington will continue to shift deck chairs on the financial Titanic.

This is not just a matter for technical debates amongst economists ${ }^{51} \mathrm{~A}$ great many public relations dollars have been invested in the idea that, for example, a new group at the World Bank (Wolfensohn and Stiglitz) will sort out the maniacs across the road at the IMF. South Africa's premier newspaper, the Mail and Guardian reported after a high-profile January 1999 trip to South Africa,"Reflecting the changing face of the World Bank, Joseph Stiglitz is a hero in some left-wing circles ... His intention is noble: to free the poor from the powerlessness that is such a feature of poverty. ${ }^{\prime 52}$

By late 1998, Stiglitz claimed, however dubiously, that 75-80 percent of his senior Bank colleagues agreed with him, so his information-theoretic analytical innovations should be seen in institutional context. Brown University political economist Robert Wade attributed the Bank's new openmindedness to an acknowledgement of internal intellectual sclerosis, Japan's increasing donor role (and its own self-interest in expansionary not contractionary policies for countries in which its firms invested), and self-reflective case study, including the counter-intuitive East Asian miracle. ${ }^{53}$

Indeed, the disjuncture between the status-quo oriented CamdessusSummers-Greenspan-Fischer bloc and reformers centred around Stiglitz boiled down, ultimately, to an elite fight between hostile brothers. Precisely the institutional role Stiglitz had to continue playing-defending a key Washington Consensus institution, the World Bank-led soon enough to his South African delegitimisation. In January 1999, his World Bank Pretoria-based colleagues set up a formal meeting with 50 members of the SA NGO Coalition (Sangoco), where Stiglitz went on to reverse tack on the larger economic issues (including his Helsinki-speech consent to allowing inflation rates to rise to 40 per cent-he reduced the figure to 8 ), once some embarrassing questions about "moral hazard" were put to him. As recounted 
by Sangoco vice president Mercia Andrews and Campaign Against Neoliberalism in South Africa coordinator George Dor,

We asked him for his views on the contradiction between his speech in $\mathrm{Hel}$ sinki and the World Bank contribution to the [homegrown structural adjustment] Gear strategy. He told us he didn't know much about South Africa ...We put it to him that perhaps the Bank should take action against its staff members on the Gear team who got the employment predictions so horribly wrong by suggesting that Gear would generate hundreds of thousands of jobs each year when, in reality, hundreds of thousands are being lost. Everything in his tortuous reply suggested that he was not particularly concerned whether Bank staff members produce work of poor quality and that staff members can get away with shoddy work that has a profound impact on people's chances of finding employment ...

Our engagement with him highlights a significant retreat from his Helsinki position. There are a number of possible reasons. His Helsinki speech may have been a deliberate strategy to create the impression of change. He may have been reigned in by the World Bank after Helsinki. Perhaps he felt restrained in Johannesburg by the need to talk the language of his entourage. He portrays the confidence that he has the ear of the institution but insider talk suggests that he is a maverick who is not to be taken too seriously. Whatever the reason for his retreat, his hero's halo has now vanished. ${ }^{54}$

But even if reforms according to Washington - either now or Post - are as capricious and shallow as Stiglitz indicated to the Johannesburg NGOs, and as the June 1999 Cologne G-7 meeting confirmed to all other observers, we must broach the larger question of what kind of political strategy leads to what kinds of change. Given the character of the (overaccumulation) crisis, it would indeed be logical to move from a marxian analysis to a revolutionary socialist strategy. But there is so little in the way of organisation aiming in this direction that it would be futile.

Instead, as ever, given the contradictory opportunities for alliance amongst various social forces arrayed against Washington implied above, the project of thorough-going reform calls up-for those who analyse the problems as being structural-the need for non-reformist reform (not, hence, reformist-reform) strategies, rather than the kinds of ameliorative or delaying tactics that we have come to expect from most of the other players. However, unlike Washington's best thinkers, some such reformers attempt to save the system from its own worst tendencies, and so it may be worth revisiting Keynes' ideas to identify what, at the very minimum, an intelligent and farsighted defender of capitalist economics understood as the appropriate institutional arrangements for financial markets.

In 1936, Keynes devised a philosophically-grounded analysis-based on the disjuncture between savings and investment that recurs periodically under capitalism - and a remedy to Depression-ridden capitalism that in turn, from the early 1940s, revolutionised economic thinking for a period of more than three, relatively high-growth, relatively less unequal decades. That remedy is famously considered to lie in fiscal populism, but just as crucial, for Keynes, was controlling financial capital that otherwise flows merrily around the world, in a twinkling of an eye, doing enormous damage. For Keynes, a footloose flow of capital "assumes that it is right and desirable to have an equalisation of interest rates in all parts of the world. In my view the whole management of the domestic economy depends upon being free to have the appropriate interest rate without reference to the rates prevailing in the rest of the world. Capital controls is a corollary to this, ${ }{ }_{55}$

Thanks largely to Keynes (arguing in 1944 against the American negotiating team at Bretton Woods), the IMF Articles of Agreement still allow member countries to "exercise such controls as are necessary to regulate international capital movements" - although, insanely, the IMF has attempted (so far unsuccessfully) to undo such a significant concession. As recently as 1990, 35 countries retained formidable capital controls, although the details (especially the technical policing capacity) ate terribly important to study. If indeed capital controls might become a common denominator of potential alliance activity amongst and between New Social Movements, they probably should be understood as a "necessary but insufficient" strategic priority for lobbying national elites and for opening up sufficient manoeuvreing space globally. Their merit is not only to go some way towards technical resolution of problems, but also to limit the damage done by the Washington Consensus in other spheres of economic and social policy engineering - simply because there is less of a need for an IMF Seal of Approval if fewer hot-money brokers are interested in a particular country.

There are related areas of nation-state intervention, such as prohibiting certain kinds of deregulated financial market activity, which should also be promoted. Indeed, a gathering at the Institute for Policy Studies in Washington in December 1998 established a variety of other approaches, such as proposed regional crisis funds (belonging to a manageable set of coun- 
tries with similar norms, values and practices) and domestic redirection of locally-raised moneys (hence "soft currency" in many cases, intermediated by worker-influenced pension funds or mutual funds) along with progressive national taxation.

Is the nation-state, though, the right scale at which to pursue reforms, or has the world changed sufficiently since Keynes time that it is now crucial to construct global not local regulatory processes? A debate continues within a branch of sociology - the World Systems Perspective-about the character of strategic engagement with the globalisation process, and it is helpful to draw out the arguments to illustrate the strategic options. Perhaps the strongest possible case in favour of a "world state" was a book published in 1992 by Warren Wagar, ${ }^{56}$ positing a global social democratic political party taking control of world government midway through the twenty-first century. This general theme has circulated for some time, and The Spiral of Capitalism and Socialism (Lynne Rienner 1999) a book by Terry Boswell and Chris Chase-Dunn, ${ }^{57}$ makes the argument forthrightly:

a world polity of global institutions, for the first time ever in world history, is becoming capable of directing the processes of the modern world-system...

"Global governance" has increased geometrically in the period following World War II as the strength of a globally-oriented world bourgeoisie has increased $v i$ s- $\dot{a}$ - $v$ is the nationally-oriented fractions of capital. These processes, like market integration, are driven by the falling costs of communications and transportation and the increasing size of business enterprises. They are also driven by the interaction between the logic of capitalist accumulation and the organizational efforts by people to control and to protect themselves from market forces.

The formation of a global polity opens the possibility of alternate paths to hegemony and even of a transformation of the system to include a world government. Of course, it is also possible, and perhaps, probable, that these changes are temporary, and that the cycle of hegemonic rivalry and war will again repeat in devastating fashion. But the possibilities for fundamentally changing the system are greater now than in the previous century.

Boswell and Chase-Dunn immediately confront potential criticism that the dominant institutions today will be terribly difficult to influence:

While the idea of a world state may be a frightening specter to some, we are optimistic about it for several reasons. First a world state is probably the most direct and stable way to prevent world war, which must be at the top of everyone's list. Secondly, the creation of a global state that can peacefully
Global Economic Crisis: A View from South Africa

adjudicate disputes among nations will transform the existing interstate system. The interstate system is the political structure that stands behind the maneuverability of capital and its ability to escape organized workers and other social constraints on profitable accumulation. While a world state may at first be largely controlled by capitalists, the very existence of such a state will provide a single focus for struggles to socially regulate investment decisions and to create a more balanced, egalitarian, and ecologically sound form of production and distribution.

The importance of this argument for many of us located in the developing world is that the semi-industrialised "semiperiphery" (which in Africa includes Egypt, Nigeria and South Africa, and possibly Zimbabwe, Kenya, Botswana, Ghana and Mauritius) is the site from which campaigns to radicalise governance of the world state would come forth. For Boswell and Chase-Dunn, "Semiperipheral locations are especially conducive to institutional innovations that have the potential to transform systemic logic. The most powerful movements toward the creation of a socialist mode of accumulation have emerged in the modern semiperiphery."

The practical implication for a country like South Africa would be continue positioning itself the way it currently is, attempting to attain leadership positions (including Mbeki's goal of taking a permanent African seat on the UN Security Council) and make major reforms to the international institutions it presently influences. Others view organisations like the NonAligned Movement or G-77 as the appropriate vehicles for making such demands. In some cases there are extremely sharp conflicts over how to reform the embryonic global state institutions. ${ }^{58}$

But even if NGOs and environmentalists continue lobbying the Bretton Woods Institutions for (ultimately quite limited) change, or if some of the more outspoken South governments continue to demand better terms and accuse the IMF of heavy-handedness, this is a long way from a coherent strategy of "democratising" the embryonic world state. The question as to how sensible such a strategy is, depends largely upon whether any real progress is being and can be made given the global balance of forces discussed above. That balance of forces has been extremely unfavorable for many years, and it is no accident that "New International Economic Order" demands have long been off the international agenda.

Perhaps because of this, the noted philosopher Iris Marion Young makes a case that although the new social movements have "affected both the dis- 
course and policies of international financial institutions" (which normally "do not even pretend to be inclusive and democratic"), instead, a "reasonable goal" for these movements is reform of the United Nations, "the best existing starting point for building global democratic institutions? Why focus on the UN?," asks Young "As members of the General Assembly, nearly all the world's peoples today are represented at the UN." Moreover, the UN is a site where imperial powers "seek legitimacy for some of their international actions" and where states "at least appear to be cooperative and interested in justice." Likewise, civil society organisations have mobilised around UN events and issues. But Young also concedes the challenges associated with such a strategy: "the world's economic powers often seek to bypass UN economic institutions altogether"; ? UN humanitarian interventions "will remain a cynical joke as long as actions with that name are organised and led by the US primarily with hardware and personnel under its national command"; ?"the entire staff of the allegedly bloated UN bureaucracies numbers about that of the State of Wyoming"; ? and the UN has perpetual financial problems (hence, Young argues, "Any social movement for strengthening global democracy and inclusion must work to shame states like the United States, who refuses to pay the dues it owes to the United Nations at the same time that it exercises its Security Council power"), ${ }^{59}$

On the contrary, therefore, an entirely different strategic orientation to global government emerged from a section of the world-systems scholaractivist community, resulting in entirely different tactical advice. As Arrighi, Hopkins and Wallerstein argued in their 1989 book Anti-Systemic Movements, the most serious challenge to the capitalist mode of production occurs when "popular movements join forces across borders (and continents) to have their respective state officials abrogate those relations of the interstate system through which the [neoliberal] pressure is conveyed." ${ }^{\prime 60} \mathrm{I}$ interpret this line of argument as saying uneven development is being exacerbated by globalisation, hence the class-forming process - by which a global proletariat is created (and ultimately forms the basis for global social justice) - is being perpetually disrupted by the destruction of working-class power. Partly for technical economic reasons similar to those Keynes considered, I endorse this point of view.

The most urgent practical implication of this latter view would probably be to campaign against the current character of most nation-states' interna- tional economic-especially financial (hard currency debt and hot-money portfolio investment) - relations. Jubilee 2000 is the most advanced of the movements working in this regard, although the other networks at this conference are equally well-positioned and capable of advocacy to continue to make their impact. Jubilee 2000 is, however, deeply split over strategies and tactics, with some of the Northern groups (particularly more moderate components of the US affiliate) ready to accept extremely weak changes to the Highly-Indebted Poor Countries (HIPC) initiative, and many of the Southern groups now taking an increasingly principled stand against HIPC itself. This kind of conflict may well be unavoidable, given the different positions.

A similar wedge issue for the international progressive movement during the 1990s was the effort of some NGOs and trade unions to reform the World Trade Organisation and other bilateral trade arrangements, through social, labour and ecological clauses associated with trade. This strategy had two problems, namely its close association with Northern protectionist tendencies and the failure by most Northern unions and environmentalists to consult with affected Southern unions and people's movements. Consequently, quite powerful South voices (like the Third World Network) spoke out very critically against the Northern progressive reformers.

In general, the various good-faith efforts of New Social Movement allies in Washington and other settings to establish reforms of the World Bank-along green, gender, transparency and participation lines, or via the very uneven Structural Adjustment Participatory Review Initiative - suffer from their reification of the embryonic global state ${ }^{61}$ In the field of international finance, for example, establishing a global regulatory body will not be easy in any event, nor - if the WTO is anything to go by - would the social movement perspective initially be given any credence whatsoever in such a body. Working with international lenders to establish bankruptcy arrangements has similar dangers, yet the need for so many of our sovereign states to find a way to go bankrupt formally is not in question; and, as noted, debt relief (especially with HIPC-style conditions), if pursued along the lines Clinton and even the Post-Washington Consensus forces recommend, will potentially do more harm than good ${ }^{62}$

What is required to resolve this cross-purpose activity, is growing political maturity and sophistication by social movement strategists who attempt 
to reflect upon, if not speak in the name of, the popular struggles occurring in each national setting. Those struggles have common roots, and we have common enemies coming out of the woodwork of the decaying international financial (and broader economic) architecture. The implications of this analysis are that some of the creakiest parts of the current framework may have to be allowed to crash; more IMF bailouts for New York investment banks - with or without a coming Wall Street crash-simply reproduce the moral and economic hazard that the Washington Consensus and international financiers will continue the status quo. The bailouts should be resisted, first and foremost, including the IMF's regular calls for more taxpayer funding to replenish its bailout funds.

But what we in the social movements can do far more rigorously than we have to date, is to establish whether our core tasks are thinking globally and acting globally, or perhaps - more strategically? — think globally, act globally, but redefine the economic and financial systems that we desperately depend upon for a less uneven form of capitalist development, at the scale of the nation-state.

\section{CONCLUSION‡ SPIRITS OF SOLIDARITY*}

The uneven development of global capitalism is, as ever, mirrored in the uneven development of resistance to global capitalism. This is even more striking in the context of crisis, when so many opportunities and dangers rise together. In drawing our conclusions about the strategic implications, a few words about agency are required so that these arguments do not suffer the fate of so many excessively abstract conceptualisations of world-systemic anti-capitalist struggle.

Although not the subject of this essay, a central implicit argument is the difficulty in relying upon either traditional class conflict (at the point of production) or marxist-leninist party-building activity as sites at which we can most reliably locate and nurture resistance to the most damaging of global capitalist processes. While justifiably cautious about claims by (postmodern) proponents of new social movements, the eminent labour journalist Kim Moody has noted a major trend in international social-movement trade-unionism beginning in the mid-1990s: the growing separation or independence of the unions from political parties they had been dominated by (usually Communist or nationalist) or dependent upon (social democratic) but whose leaders and professional politicians had moved closer to the neoliberal, pro-market policies of the parties of capital. While the unions might continue to support the parties of the left electorally, they would now shape their own political agenda. This was partly the case for many unions in Canada, and even more so for those in Europe formerly associated with Communist Parties, as in France, Spain and Italy, and for labour federations across Asia, Latin America, and Africa. ${ }^{63}$

After all, under generally less propitious conditions than South Africa, Moody observed, a series of political mass strikes by national workers' movements had shaken Nigeria, Indonesia, Paraguay and Taiwan in 1994; Bolivia, Canada and France in 1995; Argentina, Brazil, Canada, Greece, Italy, South Korea, Spain and Venezuela in 1996; Belgium, Colombia, Ecuador, Haiti, and South Korea in 1997; and then with the 1998-99 crisis, many other important sites of East Asian, East European, African and Latin American proletarian suffering due to neoliberal economic disaster. Internationalist solidarity was also evident here and there during the recent period, with Liverpool and Australian dock workers and Renault workers finding allies, as well as the emergence of wide-ranging campaigns by labour-social movement coalitions against unacceptable wages and working conditions.

Rising militancy as the long economic downturn proceeded was logical enough. As global uneven development heightened during the 1980s-90s, the displacement of the overaccumulation crisis-particularly footloose financial capital -into new areas of the world, or into new (and increasingly unbearable) kinds of class/labour/gender/ethnic relations in the advanced industrial countries, has become far more frenetic. Observers are increasingly aware of the symptoms : rising inequality, widespread child labour, booming sweatshops, declining social wages, unemployment-enhanced xenophobia and nationalist resurgences, superexploitation of women, massive ecological destruction and the like. But it is not just "space" - and relatively weaker conditions of eco-social solidarity in favoured transnational corporate investment zones - that served capital's need to move the crisis around. The use of time as a means of displacing overaccumulation is also critical to capitalist crisis management at the turn of the centuryः not just more rapid transport and communications, and "speed-up" on the production line in the context of flexibilised labour markets, but also rising indebtedness so that 
today's consumption (personal, corporate and sometimes government) can be paid back with income later.

This means that even if progressive political activists desire, ultimately, a "globalisation of people, not of capital," global capital flows will have to be more explicitly confronted, and with more and more sophisticated kinds of solidarity. Thanks to the Internet, emails and faxing, the movements' attacks upon neoliberal global economic managers are becoming incredibly surgical, exemplified by the 1997-99 obstruction of the Multilateral Agreement on Investment (that "multinational corporate bill of rights," as it was known).

Still, the political basis for new international networking remains uncertain. Peter Waterman's typology of six kinds of solidarity-Identity, Substitution, Complementarity, Reciprocity, Affinity and Restitution-helps contextualise the uncertain ways forward. As Waterman explains, "Each of these has its own part of the meaning of international solidarity; each is only part of the meaning, and by itself can only be a limited and impoverished understanding of such"

+ Identity is expressed by the slogan "Workers of the World Unite?", implying one long-term general interest;

- Substitution is exemplified by development cooperation, or "standing in" for the poor, exploited and powerless;

+ Complementarity is the solidarity of "differential contribution" to a common interest or aim (which could be between workers, or North-South);

- Reciprocity is the exchange of similar quantities or qualities over time;

+ Affinity suggests personal identity/friendship between, say, ecofeminists, socialists (of a particular hue), or even stamp-collectors;

+ Restitution is recognition and compensation for past wrongs. ${ }^{64}$

The semiperiphery will probably play quite an important role in defining which kinds of solidarity emerge and synthesise amongst the world's more progressive political-economic, cultural, single-issue and political movements of the early 21 st century. If so, the influence of "CoNGOs" in promoting international "substitutionist"-reformism as the goal of international solidarity will logically wane, ${ }^{65}$ and the search for radical local, regional and conceptual "alternatives" - a matter taken up again below - may intensify*

With respect to resistance strategies, the need to reduce the stranglehold that international financiers maintain on national leaders is still considered an extremely high priority. Different ways of approaching this defensive struggle have emerged in South Africa, ${ }^{66}$ but there can be no doubting the enormous importance of reasserting democracy and sovereignty, against the likes of the powerful financier quoted during the counting period just three days after the country's second democratic election (before the final vote tally was released), in June 1999.

Foreign investors were becoming increasingly anxious yesterday at the prospects of the ANC winning a two-thirds majority in Wednesday's general election, with a major investment fund warning this may have a devastating effect on local financial markets. Mark Mobius, the president of the $\$ 40$ billion Templeton Emerging Market Fund, said he would fundamentally alter his investment view of the country if the ANC won 67 percent of the vote. Mobius, one of the most respected emerging market investors, administers the $\$ 40$ billion fund, one of the largest investors in South Africa's financial markets. It is heavily weighted towards the country, at $8.5 \%$, or about $\$ 3.4$ billion. "If the ANC gains the power to unilaterally amend the Constitution, we will adopt a very conservative and cautious approach to further investment."

Whether ANC leaders therefore must and will adopt, in their second term of rule, conservative and cautious approaches to redistribution, reconstruction and development, remains to be seen. But for progressive South Africans, other citizens of semiperipheral societies, and their international allies, the most immediate political conclusion should be just as obvious as that drawn by Mobius (more democracy equals less investment): "delinking." For as civil society pressure increasingly compels politicians and bureaucrats to question the interstate relations which convey neoliberal pressure, then what? From Africa's leading radical economist, Samir Amin, has come the theme of regional delinking:

The response to the challenge of our time imposes what I have suggested naming "delinking" ... Delinking is not synonymous with autarky, but rather with the subordination of external relations to the logic of internal development ...Delinking implies a "popular" content, anti-capitalist in the sense of being in conflict with the dominant capitalism, but permeated with the multiplicity of divergent interests. ${ }^{68}$ 
As unrealistic as this appears at first blush, the recent, present and forthcoming conditions of global economic crisis appear to both demand and supply the material grounds for a profound change in power relations. The ideological hegemony and financial stranglehold that neoliberalism and its sponsors have enjoyed are discredited and could fast disappear. Out of nowhere (East Asia!), after all, suddenly appeared system-threatening contradictions.

And out of radical social and labour movements come, increasingly, demands that can only be met through greater national sovereignty and regional political-economic coherence. The global scale may one day appear as a likely site of struggle (for example, through the United Nations system which at least conceptually could be democratised, unlike the Bretton Woods institutions). But realistic "alternatives" are probably going to have to be fought for and won at national and regional scales. ${ }^{69}$ Such alternatives themselves need to be contextualised in power relations that are still to be fought for, Canadian labour radical Sam Ginden reminds us:

The real issue of "alternatives" isn't about alternative policies or about alternative governments, but about an alternative politics. Neither well-meaning policies nor sympathetic governments can fundamentally alter our lives unless they are part of a fundamental challenge to capital. That is, making alternatives possible requires a movement that is changing political culture (the assumptions we bring to how society should work), bringing more people into every-day struggles (collective engagement in shaping our lives), and deepening the understanding and organisational skills of activists along with their commitment to radical change (developing socialists). ${ }^{70}$

That commitment has already begun to take on international proportions through New Social Movements, Michael Lowy suggests:

Militant trade-unionists, left-wing socialists, de-Stalinized communists, undogmatic Trotskyists, unsectarian anarchists, are seeking out the paths to renewal of the proletarian internationalist tradition ....Concurrently, new internationalist feelings are becoming visible in social movements with a global perspective, like feminism and environmentalism, in antiracist movements, in liberation theology, in associations devoted to human rights and to solidarity with the third world ...It is from convergence between renewal of the socialist, anticapitalist and anti-imperialist tradition of proletarian internationalism - ushered in by Marx in the Communist Manifesto - and the universalist, humanist, libertarian, environmentalist, feminist, and democratic aspirations of the new social movements that can and will arise twenty-firstcentury internation alism. ${ }^{71}$
In a previous epoch-one recent enough in the collective memory and still bursting with the pride of authentic struggle - not more than a few thousand South African radical civil society activists took up a task of similar world-scale implications. In part, the struggle was to open up space for a developmental liberation (even if that space was quickly closed, and unnecessarily so, we have argued). A core component of the strategy was severing international elite relations with (and support for) apartheid, as Arrighi et al propose for the anti-neoliberal struggle. As impossible as the activists' anti-apartheid mission appeared during the darkest days, they won! Given the rapid shifts in power and the crisis of elite interests now being played out across the world, the multifaceted campaigns against Washington-and against those in southern capitals who serve as its parrots - still rank amongst the very highest priorities of South African progressives and their allies.

The era of an economic context in which Washington-oriented policymakers went unchallenged is nearing an end, it appears. It remains for the world's various strains of progressive politics - always in alliance with others concerned about meeting human needs and invoking ecological values - to more forcefully show how the existing social and environmental programs of what we've termed New Social Movements can become (or contribute to) the foundation of an entirely different economic development strategy. Such efforts should receive the solidarity of progressives across the worldsystem - in activist and intellectual communities alike.

\section{NOTES}

1.Associate Professor, University of the Wit watersrand Graduate School of Public and Development Management, Johannesburg (pbond@wn.apc.org); and Research Associate, Alternative Information and Development Centre (http:llaidc.org.za). Commentary in the pages below was presented in various forms at conferences and seminars in Harare, Ottawa, Washington, Maputo, Johannesburg, Bangkok, Yokohama, Lusaka and Manzini, Swaziland between September 1998 and August 1999; commentators and critics are thanked for inputs. The arguments are elaborated in my forthcoming Elite Transition: From Apartheid to Neoliberalism in South Africa, London, Pluto Press.

2.Michel Camdessus, 'Capital Flows, Crises and the Private Sector,' Remarks to the Institute of International Bankers, Washington, DC, 1 March 1999, p.9.

Criticism is not meant to discount the ultimate desirability of some kind of humane sovereign-bankruptcy mechanism to clear debt, but it could only legitimately take the form of an arbitration panel with United Nations jurisdiction rather than a cartel of 
lenders bedeviled by the IMF's conflicts-of-interest and austerity orientation.

3. The ANC adopted a homegrown structural adjustment programme-Growth, Employment and Redistribution (Gear) - in 1996. Looking at the three-year period 1996 98, virtually all Gear's targets were missed. Annual GDP growth fell from 3.2 to 1.7 to 0.1 percent in 1996, 1997 and 1998, instead of the strategy's projection of 3.5, 2.9 and 3.8 percent growth. (In view of steady population growth, the per capita wealth of South Africa actually fell by 2.5 percent.) Formal sector (non-agricultural) job losses were 71,000,126,000 and 186,000, instead of Gear's anticipated employment gains of $126,000,252,000$ and 246,000 . The rate of increase in private sector investment fell from 6.1 to 3.1 to a negative 0.7 percent in 1996, 1997 and 1998 (instead of rising 9.3, 9.1 and 9.3 percent, respectively). Of private investment, virtually all foreign direct investment was related to the purchase of existing assets through privatisation and merger/acquisition deals (particularly the 30 percent sale of Telkom) as opposed to new plant and equipment, and South African outflows of foreign direct investment ( $\$ 2.3$ billion in 1997) were far higher than what came in ( $\$ 1.7$ billion that year). Savings also fell (notwithstanding the rise in the real interest rate from 1996-98) from 18 percent of GDP in 1996 to 15 percent in 1997 and 14 percent in 1998; private savings fell from 20 percent in 1996 to 17 percent in 1998 (instead of rising to 21 percent, as Gear forecast). The current account deficit worsened from - 1.3 percent in 1996 to -2.1 percent in 1998 (instead of remaining stable, as Gear predicted). Exports of South African products (other than gold) rose slowly in 1997-98 (5.3 and 2.1 percent, respectively), confounding Gear projections (of 8 and 7 percent, although 1996 export growth was better than predicted). The real interest rate remained in double digits from 1996-98 (instead of falling from 7 to 5 to 4 percent, as Gear hoped), and the value of the rand collapsed from 3.5 to the dollar in mid-1996 to 6 (at one point, 6.7) in 1998, confounding projections that it would stay relatively stable (National Institute for Economic Policy, NGQO!: An Economic Bulletin, 1, 1, http: llwww.niep.org.zal, pp.1-3).

4. ANC Alliance, 'The Global Economic Crisis and its Implications for South Africa,' Discussion Document, Alliance Summit, Johannesburg, 24 October 1998, pp. 2,3 .

5. Talk given to the September 1998 Commonwealth finance ministers' meeting in Ottawa, cited in my 'Time Again for the Finrand,' Mail and Gtzardian, 16 October 1998. Manuel proceeded, however, to confirm the Washington Consensus in his subsequent budget speeches, reflecting that even if analysis was moving forward, international financial power relations remained locked in place.

6. ANC, 'The State, Property Relations and Social Transformation,' ANC Discussion Document (mimeo) reprinted in the African Communist, 4th quarter 1998, pp.13-14.

7. According to James Love, director of the Consumer Project on Technology and an associate of consumer advocate Ralph Nader, "For some drugs this reduces the price by 70 to 95 percent, depending upon manufacturing costs. Several of the drugs that are candidates for compulsory licensing, including $\mathrm{AZT}$, $\mathrm{ddI}$ and $\mathrm{ddC}$, were developed by the U.S. National Institutes of Health." For details, see my "Globalization, Pharmaceutical Pricing and South African Health Policy: Managing Confrontation
Global Economic Crisis: A View from South Africa

with U.S. Firms and Politicians,' International Journal of Health Services, 29, 4, 1999.

8. Was this, however, a case of "talking left, acting right"? Within the next few weeks, several huge corporations-including Anglo American Corporation, Old Mutual, Liberty Life and South African Breweries - voted with their feet by moving large chunks of capital and stock market listings to London, without any hint of resistance from Manuel. The subsequent (February 1999) ANC budget dropped corporate taxes from 35 per cent to 30 per cent (the ANC had inherited a 48 per cent corporate tax rate in 1994), while cutting (in real terms) pensions for elderly poor people (to less than $\$ 80$ per month). Emblematically, Firoz Cachalia (a leading ANC politician in Johannesburg) appealed to a Business Day readership just prior to the June 1999 election,

Fiscal and monetary constraint and liberalised trade and capital movements ...which aim at the structural repositioning of SA's economy in response to globalisation, whatever their long-term benefits, have severe short-term costs for constituencies of votes who are among the current supports of the governing party. The ANC has, however, indicated that it will persist on its chosen path ...Contrary to the conventional wisdom that the alliance between the governing party and trade unions limits economic growth, there is considerable evidence that such relationships make growth possible through wage restraint. 1999.)

(Cited in my 'The African National Congress Landslide,' GreenLeft Weekly, 8 June

9. ANC Alliance, 'The Global Economic Crisis,' p.4.

10. I am reliably informed that the Brenner article impressed Netshitenzhe and SACP intellectuals Blade Nzimande and Jeremy Cronin. An updated version was published as a book: Robert Brenner, Turbulence in the World Economy, London, Verso, 1999.

11. Koh Young-joo, 'Alternatives to the "Corporate State"?,' Paper presented to Conference on 'Economic Sovereignty in a Globalising World,' Bangkok, 24 March 1999.

12. I take as at least evidence of empirical support for such patterns the work of Christian Suter, Debt Cycles in the World Economy, Boulder, West view Press, 1992.

13. I have carefully documented one small country's repeated patterns of overaccumulation-speculation-unevenness in Uneven Zimbabwe: A Study of Finance, Development and Underdevelopment, Trenton, Africa World Press, 1998. For South African evidence, see C.G.W. Schumann, Structural Changes and Business Cycles in South Africa, 1806-1936, London, P.S.King and Son, Ltd, 1938; Charles Meth, 'Productivity and South Africa's Economic Crisis,' Research monograph, University of Natal/ Durban Department of Economics, 1990; and my Commanding Heights and Community Control, Johannesburg, Ravan, 1991 and 'A History of Fin ance and Uneven Development in South Africa,' South African Geographical Journal, 80, 1, 1998.

14. For this statement, I draw here upon theoretical (and to some extent empirical) accounts by contemporary political-economists Samir Amin, Robert Brenner, Simon 
Clarke, Diane Elson, Ben Fine, David Harvey, Dani Nabudere, Neil Smith and Ellen Meiksins Wood, among others. Important differences can be set aside for the sake of establishing a relatively common understanding of the laws of motion of capitalism.

15. In addition to Brenner's more recent statement of the evidence, see earlier discussions about 1970s-80s stage of the global crisis, such as Simon Clarke, Keynesianism, Monetarism and the Crisis of the State, Aldershot, Edward Elgar, 1988, pp.279-360; David Harvey, The Condition of Postmodernity, Oxford, Basil Blackwell, 1989, pp.180-197; Ernest Mandel, 'Theories of Crisis: An Explanation of the 197482 Cycle,' in M. Gottdiener and N. Komninos (Eds), Capitalist Development and Crisis Theory: Accumulation, Regulation and Spatial Restructuring, London, Macmillan, 1989, pp.30-58; Keith Armstrong, Andrew Glyn and John Harrison, Capitalism Since 1945, Oxford, Basil Blackwell, 1991, pp.169-260.

16. Seminal moments of devaluation included the Third World debt crisis (1980s), energy finance shocks (mid 1980s), crashes of international stock (1987) and property (1991-93) markets, and the long, terribly deep crash (from 1973-99) of non-petroleum commodity prices. Sometimes devaluation of financial assets backlashed, however. Late-1990s examples of gambles gone very sour in derivatives speculation, exotic stock market positions, currency trading, and bad bets on commodity futures and interest rate futures include Long-Term Capital Management ( $\$ 3.5$ billion)(1998), Sumitomo/London Metal Exchange ( $£ 1.6$ billion)(1996), I.G.Metallgessellschaft (\$2.2 billion)(1994), Kashima Oil (\$1.57 billion)(1994), Orange County, California ( $\$ 1.5$ billion)(1994), Barings Bank ( $£ 900$ million)(1995), the Belgian government ( $\$ 1$ billion)(1997), and Union Bank of Switzerland (\$690 million)(1998).

17. In an important over view of the debate over global financial reform, Walden Bello, Kamal Malhotra, Nicola Bullard and Marco Mezzera ('Notes on the Ascendancy and Regulation of Speculative Capital,' Paper presented to the Conference on 'Economic Sovereignty in a Globalised World,' Bangkok, 24 March 1999) argue that there are three main positions on global financial reform: 'It's the wiring, not the architecture' (Washington Consensus plus Group of 22), 'Back to Bretton Woods' (a strong version of Post-Washington Consensus), and 'It's the development model, stupid!' (New Social Movements) - ignoring the far right critique and collapsing nationalists and post-Wash-Con economists into the second category.

The term "Washington Consensus" comes from John Williamson, "The Progress of Policy Reform in Latin America,' Policy Analyses in International Economics, Washington, DC, Institute for International Economics, 1990. As one minor personal indication of the awesome power invested in Wash-Con leaders, Time magazine (15 February 1999) anointed Rubin, Summers and Greenspan the 'Three Marketeers' who could save the world from depression.

The arrogance of Consensus-think was evident in Camdessus's description of the Asian crisis as a 'blessing in disguise' (Wall Street Journal, 24 September 1998). Illustrative of crisis-era justifications are articles and speeches by Robert Rubin, 'Strengthening the Architecture of the International Financial System,' Remarks to the Brookings Institution, Washington, DC, 14 April 1998; by Laurence Summers, 'The Global Economic Situation and What it Means for the United States,' Remarks to the
Global Economic Crisis: A View from South Africa

National Governors' Association, Milwaukee, Wisconsin, 4 August 1998; by Stanley Fischer, 'IMF-The Right Stuff,' Financial Times, 17 December 1997, 'In Defence of the IMF: Specialized Tools for a Specialized Task,' Foreign Affairs, July-August 1998, and 'On the Need for an International Lender of Last Resort,' IMF Mimeo, Washington, DC, 3 January 1999; and by Michel Camdessus, 'The IMF and its Programs in Asia,' Remarks to the Council on Foreign Relations, New York, 6 February 1998. (See also Organisation for Economic Cooperation and Development, Report of the Working Group on International Financial Crises, Paris, 1998.)

18. See Jagdish Bhagwati, "The Capital Myth: The Difference between Trade in Widgets and Trade in Dollars,' Foreign Affairs, 77m, 3, May/June 1998. Dornbush cited in Doug Henwood, 'Marxing up the Millennium,' Paper presented to the 'Marx at the Millennium' Conference, University of Florida, 19 March 1999.

19. For a good description, see Richard Leaver, 'Moral (and Other) Hazards: The IMF and the Systematic Asian Crisis,' Paper presented to Conference on 'Economic Sovereignty in a Globalising World,' Bangkok, 24 March 1999. For their own words, see Cato Institute, http://www.cato.org/research/glob-st.html; Henry Kissinger, 'IMF no Longer Able to Deal with Economic Crises,' Los Angeles Times, 4 October 1998; George Shultz, William Simon and Walter Wriston, 'Who Needs the IMF?, Wall Street Journal, 3 February 1998.

20. G. Franke-Ruta, 'The IMF Gets a Left and a Right,' The National Journal, 30, 3, 1998.

21. Joseph Stiglitz, 'More Instruments and Broader Goals: Moving Toward a PostWashington Consensus,' WIDER Annual Lecture, Helsinki, 7 January 1998. See also his 'Towards a New Paradigm for Development: Strategies, Policies, and Processes,' Prebisch Lecture, UN Conference on Trade and Development, Geneva, 19 October 1998. Illustrative of Stiglitz's attack on conventional wisdom-including self-corrective financial markets (for which his two decades work will no doubt soon be rewarded with a Nobel Prize) - are the following lines from the Helsinki paper: "the policies advanced by the Washington Consensus are hardly complete and sometimes misguided ...the advocates of privatization overestimated the benefits of privatization and underestimated the costs ... [below $40 \%$ per year] there is no evidence that inflation is costly...The focus on freeing up markets, in the case of fin ancial market liberalisation, may actually have had a perverse effect, contributing to macro-instability through weakening of the financial sector."

22. In The Crisis of Global Capitalism: The Open Society Endangered (New York, Public Affairs, 1998), Soros asserts, "To put the matter simply, market forces, if they are given complete authority even in the purely economic and financial arena, produce chaos and could ultimately lead to the downfall of the global capitalist system." In another article-'Avoiding a Global Breakdown,' Financial Times, 31 December 1997-he specifies what is wrong with financial market forces: "The private sector is ill-suited to allocate international credit. It provides either too little or too much. It does not have the information with which to form a balanced judgment. Moreover, it is not concerned with maintaining macroeconomic balance in the borrowing countries. Its goals are to maximize profit and minimize risk. This makes it move in a herd-like fashion in both 
directions. The excess always begins with overexpansion, and the correction is always associated with pain."

23. In a perceptive review of the 1998 book, Doug Henwood ('Let George Do It,' Left Business Observer 88, February 1999) argues that Soros has lifted from postKeynesian economist Paul Davidson unattributed arguments about financial market disequilibrium ('nonergodicity'), and that his analysis is far less convincing in these matters than Keynes, Joan Robinson, Karl Polanyi and Hyman Minsky-who pioneered theories of imperfect financial markets long before Stiglitz. (Stiglitz told me personally that he did not take terribly seriously the ideas of Soros, whom he saw mainly as a practitioner with insufficient intellectual distance; interview, 1 October 1998, Ottawa.)

Most tellingly, Soros' solutions wilt when it comes to national exchange controls, and at a time when honest economists were reviewing this once widely-practiced technique as part of the solution to financial market turbulence - and at a time Stiglitz, who initially worried that the September 1998 Malaysian exchange controls represented 'too much of a backlash' (preferable, he told me three weeks later, were dual-currency controls like South Africa's 1985-95 finrand), prepared to endorse Malaysia's controls. After all, Stiglitz conceded in mid-1999, 'There was no adverse effect on direct foreign investment ...there may even have been a slight upsurge at some point' (Agence France Press, 23 June 1999). Soros, whose famous tiff with an evidently anti-semitic Mohamad Mahathir in 1997-98 may have influenced matters (Economist, 27 September 1997), shied well away from exchange controls, for if widespread, these would end his speculating days. And as Henwood concludes of Soros' insurance proposal, 'Making creditors bear the risk of lending beyond sanctioned limits might not do all that much' to cool down hot money flows in any event.

24. Sunday Independent, 16 May 1999.

25. Paul Krugman, 'Saving Asia: It's Time to get RADICAL,' Fortune, 7 September 1998.

26. Jeffrey Sachs, 'The IMF is a Power unto Itself,' Financial Times, 11 December 1997; 'The IMF and the Asian Flu,' The American Prospect, March-April 1998.

27. See especially the work of UNCTAD economist (and post-Keynesian) Yilmaz Akyuz, 'Taming International Finance,' in J.Michie and J.G.Smith (Eds), Managing the Global Economy, Oxford, Oxford University Press, 1995 and 'The East Asian Financial Crisis: Back to the Future,' in Jomo K.S. (Ed), Tigers in Trouble, London, Zed, 1998.

28. James Wolfensohn, 'A Proposal for a Comprehensive Development Framework (A Discussion Draft),' Washington, DC, World Bank, 29 January 1999.

29. Hirakawa Hitoshi, 'The Asian Monetary Fund and the Miyazawa Initiative,' Paper presented to Conference on 'Economic Sovereignty in a Globalising World,' Bangkok, 24 March 1999; Oskar Lafontaine and Christa Mueller, Keine Angst vor der Globalisierung: Worblstand und Arbeit fuer Alle, Bonn, Dietz Verlag, 1998.

30. Mohamad Mahathir, "The Future of Asia in a Globalised and Deregulated World,' Speech to the conference 'The Future of Asia,' Tokyo, 4 June 1998. In a spirit mirroring Mahathir's, other rulers of two formerly free-market Asian countries defended themselves from speculators in September 1998; the Hong Kong state prohibited the short-selling of local stock market shares and also bought $\$ 14$ billion in shares to prop up the Hang Seng index, and Taiwan outlawed what were described as illegal funds-trades by Soros hedge funds.

For background to Mugabe's hate-love-hate relations with the IMF and World Bank, see my Uneven Zimbabwe, Chapters Eleven-Twelve. There was a confused flurry in early 1999 when Mugabe sought funding elsewhere than the IMF. See, e.g., "Zimbabwe Severs 'Ties with the IMF,' Wall Street Journal, 12 April 1999 and AP Worldstream, 'We Won't Cut Ties with IMF, World Bank, says Zimbabwe,' 12 April 1999; for a more skeptical view of Mugabe's updated "socialist" rhetoric, see my 'Zimbabwe's Political Reawakening,' Montbly Review, 50, 11, May 1999. The IMF's Zimbabwe objectives were straightforward: Mugabe must reverse the only two progressive things he had done in a long time, namely the imposition of a luxury import tax in 1997 and of price controls on staple foods in mid-1998 in the wake of IMF riots. According to a blunt Michael Nowak, IMF assistant director for Africa, "There are two issues outstanding and these have stopped the IMF from making the [\$53 million] standby credit available to the country. These issues are, one, we want the government to reduce the tariffs slapped on luxury goods last September, and secondly, we also want the government to give us a clear timetable as to when and how they will remove the price controls they have imposed on some goods" (see Abel Mutsakani, "IMF says Tariffs, Price Controls Last Hurdles to Aid, Financial Gazette, 12 March 1999). Later in 1999, the IMF agreed to increase the loan amount to $\$ 200$ million, but according to an IMF official, yet more conditions emerged, namely, access to classified Congo war information and a commitment to a fiscally-responsible source for any new war expenditure: "The Zimbabweans felt offended, shocked, but they all the same agreed to give us the information, we got all the clarification we wanted. They had no choice... We have had assurances [that] if there is budgetary overspending, there will be cuts in other budget sectors" (Agence France Press, "IMF Agrees to Lend Zimbabwe 200 Million US Dollars: IMF Source,' 20 July 1999). The final deal in August 1999 also compelled the Zimbabwe Reserve Bank to restore foreign currency accounts to local corporations. This loan represented the most blatant manipulation of Zimbabwean sovereignty ever, yet Mugabe signed.

As for Chavez, the main controversies associated with the honeymoon period following his impressive 1998 electoral victory-on an anti-poverty campaign platform-were whether he would maintain favour with the IMF through budgetary restraint and real public sector wage cuts, and how quickly and deeply he would restructure domestic political and judicial institutions. Within a month of taking office, he cut the budget by 11 percent (denying he was already an IMF devotee), notwithstanding some extra spending on public works programmes. While unions demanded a 50 percent wage increase to keep pace with inflation, Chavez offered only 20 percent in a national tripartite bargaining forum, and when that broke down imposed the negative real wage deal on public sector workers (see Reuters, "Venezuela not Negotiating, just Talking to IMF,' 3 March 1999; Associated Press, 'Venezuela faces Severe Recession,' 4 March 1999). However, given that union leaders were part of an oligarchic political structure and that simultaneously Chavez was dramatically 
increasing public works programmes in part through redirection of military personnel resources, his care regarding economic reform may not have been as decisive as was first feared. Indeed in the process of subsequently invoking an historic national constitutional assembly with mass-popular support, in the wake of a dramatic referendum on constitutional reform, the strategy of shaking loose local power relations in the political sphere as a means of addressing neoliberalism's economic legacy appeared surprisingly viable. It is too early to tell whether Chavez belongs in the same camp of nationalistpopulists who "talk left" and "act right."

31. Mandela's televised comment is cited in my "Global Financial Crisis: Why we should Care, What we should Do,' , 15, 3, 1998. This was not atypical. Jonathan Michie and Vishnu Padayachee are right to conclude that "In the South African context, globalization has become a synonym for inaction, even paralysis, in domestic economic policy formulation and implementation." (Jonathan Michie and Vishnu Padayachee, 'The South African Policy Debate Resumes' in J.Michie and V.Padayachee [Eds], The Political Economy of South Africa's Transition, London, The Dryden Press, 1997, p.229.)

32. Very different circumstances prevailed, amidst very different ideologies, but this fate befell, amongst others, Aquino (Philippines), Arafat (Palestine), Aristide (Haiti), Bhutto (Pakistan), Chavez (Venezuela), Chiluba (Zambia), Dae Jung (South Korea), Havel (Czech Republic), Mandela (South Africa), Manley (Jamaica), Megawati (Indonesia), Musoveni (Uganda), Mugabe (Zimbabwe), Nujoma (Namibia), Ortega (Nicaragua), Perez (Venezuela), Rawlings (Ghana), Walensa (Poland) and Yeltsin (Russia).

33. ANC Alliance, 'The Global Economic Crisis,' p.5.

34. In this regard, what many such movements are saying is a striking echo of John Maynard Keynes' position (in a 1933 Yale Review article): "I sympathise with those who would minimise, rather than with those who would maximise, economic entanglement among nations. Ideas, knowledge, science, hospitality, travel-these are the things which should of their nature be international. But let goods be homespun whenever it is reasonably and conveniently possible and, above all, let finance be primarily national." (John Maynard Keynes, 'National Self-Sufficiency,' Yale Review, 22, 4, 1933, p.769.)

Add political solidarity to his list of what should be globalised, and Keynes would fit nicely into this current.

35. Like those of the Philippines, South Africa, parts of Eastern Europe and Cuba.

36. From the Brazilian Workers Party, Sandinistas and their Sao Paolo Forum allies in Latin America, to the emergent new worker's party-the Movement for Democratic Change-in Zimbabwe.

37. One of the best works on such contending discourses, as applied to debates between the orthodox "ecological modernisation" approach and radical "environment justice," is David Harvey, Justice, Nature and the Geograpby of Difference, Oxford, Basil Blackwell, 1996. I outline the problem in "Environmental Discourses in South African Infrastructure Project Analysis," forthcoming in Capitalism, Nature, Socialism, 1999.

38. To cite only a few such mass movements which apparently worked well with other local and global anti-neoliberal initiatives-simply so as to give a flavour of this current-consider Mexico's Zapatistas (both the retreating army and the emerging peasant and worker civil-society organisations), Brazil's Movement of the Landless, India's National Alliance of People's Movements, Thailand's Forum of the Poor, the Korean Confederation of Trade Unions, and Burkina Faso's National Federation of Peasant Organisations. At a regional scale, an interesting example is the Sao Paulo Forum of Latin American leftists.

39. Again, by way of example, local struggles to make housing and food social entitlements - expanding the sphere of human rights discourse beyond "first generation" liberal political rights into more radical socio-economic spheres-were aggregated into the Habitat International Coalition and FoodFirst International Action Network. Other international networks had successes in banning the dumping and incineration of toxic waste (Health Care without Harm). The Zapatista "Intergalactic Encounters for Humanity, Against Neoliberalism" planted more visionary seeds, as have growing anarchist-inspired networking and activism-epitomised by the civil disobedience of the impressive network known as "Peoples' Global Action" - in London, Paris, Geneva, Davos, San Francisco and other sites of Northern power.

40. Admittedly, classic South versus North sentiments arose not only in J2000 critiques of the Washington Consensus and the highly-conditional debt relief schemes on offer from Washington, but also in J2000 South critiques of their northern advocacy counterparts, who often appeared extremely pliant to Northern politicians' gambits. For an excellent article on this topic, see Dot Keet, "The International Anti-Debt Campaign: An Activists' View from the South, to Activists in the North,' AIDC Discussion document, http: llwww.aidc.org.za.

41. Again a handful of examples will suffice, e.g, the Third World Network based in Penang and Accra, the Third World Forum in Senegal, the International Rivers Network in Berkeley.

42. Worth citing are the Nader organisations, Alliance for Global Justice, and Center for International Environmental Law.

43. For example, Focus on the Global South in Bangkok, the Preamble Center and Institute for Policy Studies in Washington, Amsterdam's Transnational Institute and International Institute for Research and Education.

44. Critical masses of political economists had amassed at London's School of Oriental and African Studies, the University of Massachusetts/Amherst, and American University in Washington.

45. In English, these included The Ecologist, Green-Left Weekly, International Socialism, International Viewpoint, Left Business Observer, Links, Monthly Review, Multinational Monitor, New Internationalist, Red Pepper, Third World Resurgence, and Z.

46. These included Pluto, Zed, Monthly Review, Verso, amongst just the Englishlanguage presses. It may be useful to list several of the radical (or "critical") Englishlanguage books - not to mention seminal articles and papers, for the list is vast - about global capitalism (and resistance) just prior to the turn of the century (here 1997 is an arbitrary cutoff because in 1996 important books were produced by Alexander, Berger and Dore, Boyer and Drache, Clarke, Helleiner, Hirst and Thompson, Hopkins and Wallerstein, Mander and Goldsmith, Michie and Grieve Smith, Robinson, and others and in 1995, etc etc): Samir Amin, Capitalism in the Age of Globalization, London, 
Zed, 1997; Robert Blecker, Taming Global Finance, Washington, DC, Economic Policy Institute, 1999; Robert Brenner, Turbulence in the World Economy, London, Verso, 1999; Catherine Caufield, Masters of Illusion, London, Macmillan, 1997; Michel Chossudovsky, The Globalisation of Poverty, London, Zed, 1997; William Greider, One World Ready or Not, London, Penguin, 1998; Robin Hahnel, Panic Rules!, Boston, South End, 1999; Doug Henwood, Wall Street, London, Verso, 1997; Ankie Hoogvelt, Globalisation and the Postcolonial World, London, Macmillan, 1997; Joshua Karliner, The Corporate Planet, San Francisco, Sierra Club, 1997; Jomo K.S., Tigers in Trouble; Hans-Peter Martin and Harald Schumann, The Global Trap, London, Zed, 1997; Kim Moody, Workers in a Lean World, London, Verso, 1997; Harry Shutt, The Trouble with Capitalism, London, Zed, 1999; Kavaljit Singh, A Citizen's Guide to the Globalisation of Finance, London, Zed and Delhi, Madhyam Books, 1998; Mrinalini Sinha, Donna Guy and Angela Woollacott (Eds), Feminisms and Internationalism, Oxford, Blackwell, 1999; Robert Wade, The Gift of Capital, London, Verso, 1999; Peter Waterman, Globalisation, Social Movements and the New Internationalisms, London, Cassell, 1998; and Linda Weiss, The Myth of the Powerless State, Cambridge, Polity, 1998.

47. In the same illustrative spirit, some of the leading anti-neoliberal spokespeople, activist-leaders and leftist luminaries of the late 1990s deserve mention: Subcommandante Marcos of the Zapatistas, Lula (Luis Ignacio da Silva) of the Brazilian Workers Party, Cuban premier Fidel Castro, Guatamalan Nobel laureate Rigoberto Menchu, Alejandro Bendana of Nicaragua, Samir Amin of the World Forum for Alternatives in Dakar, Kenyan environmentalist Wangari Maathai, South African poet Dennis Brutus of the debt cancellation movement, Indian anti-dams and social movement campaigner Medha Patkar, Martin Khor of Third World Network, Indian writer Arundhati Roy, feminist-scientist-environmentalist Vandana Shiva, Walden Bello of Focus on the Global South, former Tanzanian President Julius Nyerere, Australian journalist John Pilger, Russian intellectual Boris Kagarlitsky, Susan George of the Transnational Institute, French intellectual Pierre Bordieu, US consumer activist Ralph Nader, Montbly Review co-editor Ellen Meiksins Wood, Irish journalist Alexander Cockburn, Palestinian literary critic Edward Said, and US intellectual Noam Chomsky.

48. For instance, James Tobin, author of the international $0.05 \%$ cross-border financial transaction tax proposal which bears his name; John Eatwell and Lance Taylor, who argued for a World Fin ancial Authority; futurist Hazel Henderson who suggests means to prevent currency "bear raids" by focusing on electronic funds transfers (and a transparent transaction reporting system); or post-Keynesian Paul Davidson, who wanted an international clearing union providing for capital controls.

See James 'Tobin, 'A Proposal for International Monetary Reform,' The Eastern Economic Journal, July/October 1978; John Eatwell and Lance Taylor, 'International Capital Markets and the Future of Economic Policy,' CEPA Working Paper Series III, Working Paper 9, New School for Social Research, New York, September 1998; Hazel Henderson, Building a Win-Win World, San Francisco,Berrett-Koehler, 1996 and 'The Global Financial Casino: A View Beyond Textbook Economics,' Paper presented to Conference on 'Economic Sovereignty in a Globalising World,' Bangkok, 24 March
Global Economic Crisis: A View from South Africa

1999; Paul Davidson, 'Are Grains of Sand in the Wheels of International Finance Sufficient to do the Job when Boulders are often Required?', The Economic Journal, 107, 1997, and 'The Case for Regulating International Capital Flows,' Paper presented at the Social Market Foundation Seminar on Regulation of Capital Movements, 17 November 1998. The most progressive variants of these arguments for a global financial regulatory authority can be found at the website of the Financial Markets Center in Washington, a populist-inspired think-tank whose intellectual allies include Jane D'Arista, James Galbraith, William Darity, William Greider and Dean Baker: http: llwww.fmcenter.org.

Interestingly, a few Wash-Con and post-Wash-Con economists once engaged these issues with a degree of intellectual rigour that is surprising in retrospect, given their present reluctance to offend financial markets in substantive ways. Most notably, Lawrence Summers coauthored an article the practical implications of which he would distance himself from in later years: 'When Financial Markets Work Too Well: A Cautious Case for a Securities Transactions Tax,' Journal of Financial Services 3, 1989. Likewise, one of the most fanatical mid-and late-1990s financial-liberalisers, Stanley Fischer, argued as recently as 1991 that 'domestic firms should not be given unrestricted access to foreign borrowing, particularly non-equity financing' (in his book Isstes in International Economic Integration, Bangkok, 1991, p.20). And Stiglitz once offered a tax-based approach in the article, "Using Tax Policy to Curb Speculative Short-Term 'Trading,' Journal of Financial Services, 3, 1989 (which Davidson has ridiculed as a 'noisetrader-as-fool argument').

49. For a description of CoNGOism from a pro-IMF angle, see Jan Scholte, "The IMF Meets Civil Society,' Finance and Development, 35, 3, 1998, and 'Civil Society and a Democratisation of the International Monetary Fund,' in P.Yeros and S.Owen (Eds), Poverty in World Politics: Whose Global Era?, London, Macmillan, 1999. More generally, see Alan Fowler, 'Capacity Building and NGOs: A Case of Strengthening Ladies for the Global Soup Kitchen?', Institutional Development, 1, 1, 1994.

50. Associated Press, 29 June 1999.

51. The Post-Washington Consensus critique of Washington is reviewed above. For a critique of the Post-Washington Consensus, see especially the work of Ben Fine, including 'Industrial Policy Revisited,' Indicator SA, 15, 4, 1998; a forthcoming edited collection drawing upon the School for Oriental and African Studies 1998 99 economics seminar; and 'The Developmental State is Dead-Long Live Social Capital?' Development and Change, 30, 1, 1999. See also a discussion of implications for South Africa in my 'Moving Toward-or Beyond?-a "Post-Washington Consensus" on Development,' Indicator SA, 15, 4, 1998.

52. Mail and Guardian, 8 January 1999.

53. After Interpress Service reported in early 1998 that a Bank official joked of locking Stiglitz up in the basement to shut him up after Helsinki (and indeed it was several months before he made headlines again), I asked him in private discussion whether he'd won the battle of hearts and minds amongst his lead staff. The main student of Bank culture, Robert Wade, doubted the answer I received: "I would be surprised if the figure is anywhere close to 80 percent. What Stiglitz is saying is 
contrary to what so many have built their career espousing. I'm not quite so cynical to think that people can change their 'pre-analytic visions' as quickly as Stiglitz's figure implies-although the may change the tenor of what they say when they know it might get back to Stiglitz" (personal correspondence, 15 October 1998). See Wade's 'The Gathering World Slump and the Battle over Capital Controls,' New Left Review, 231, SeptemberOctober 1998, and 'From "Miracle" to "Cronyism": Explaining the Great Asian Slump,' Cambridge Journal of Economics, 22, 6, November 1998.

54. International Viewpoint, 310, April 1999; for an official Sangoco report on the meeting in the same spirit, see also NGO Matters, January 1999.

55. See D.Moggeridge, Ed, The Collected Works of J. M. Keynes, Vol.25, London, Macmillan, p.149.

56. Warren Wagar, A Short History of the Future, Chicago, University of Chicago Press, 1992. See reactions in Journal of World Systems Research, 2, 1996 (including Patrick Bond and Mzwanele Mayekiso, "Towards the Integration of Urban Social Movements at the World Scale').

57. Terry Boswell and Chris Chase-Dunn, The Spiral of Capitalism and Socialism, Boulder, Lynn Reiner, 1999.

58. In 1998-99 for example, major Southern governments (especially India and Brazil) argued forcefully against stronger powers for the key reforming agency within the World Bank (the "Inspection Panel," often used by development and environment NGOs to protest damaging Bank projects) — and indeed the Southern government representatives severely weakened the scope for reforming the Bank in ways which would make its loans more subject to citizen accountability.

59. Iris Marion Young, Inclusion and Democracy, Oxford, Oxford University Press, 1997, Chapter Seven. Young draws upon the work of Erskine Childers, Brian Urquhart and Chadwick Alger. A similarly strong group of proponents for the utilisation of the $\mathrm{UN}$ as a potential liberated zone are those involved in human rights work and in the UN Non-Governmental Liaison Service.

60. Giovanni Arrighi, Terence Hopkins and Immanuel Wallerstein, Anti-Systemic Movements, London, Verso, 1989, p.74.

61. There is interesting debate amongst progressive economists over one potential exception: the "Tobin Tax" campaign that is being waged in Canada, the US and France to establish a penalty for international financial transactions so as to disincentivise speculation, which can effectively be accomplished by the G-7 countries acting in concert. As formidable a marxist economist as Suzanne de Brunhoff (http: Hlwww.attac.org) has signed on to this campaign, although others (such as Leo Panitch and Gerard Greenfield of the Socialist Register) insist that national capital controls should be a higher priority.

62. Representative Jesse Jackson, Jr, pointed this out, in offering a much more progressive alternative to the Africa Growth and Opportunity Bill, called HOPE for Africa, for which he mustered support from 70 colleagues in early 1999.

63. Moody, Workers in a Lean World, p.21.

64. Waterman, Globalisation, Social Movements and the New Internationalisms, Chapter One.
Global Economic Crisis: A View from South Africa

65. CoNGO declarations of victory notwithstanding, with respect to conceptual and intellectual trends, the possibility of uniting with Post-Washington Consensus reformers was as bleak and fruitless as the prospect of mass-popular alliances with Mahathir, Mugabe and other rabid nationalists. By 1998, Stiglitz was being consistently challenged from the left through, for example, a formidable set of seminar papers given at the London School of Oriental and African Studies, which documented the merely ameliorative effects that post.Washington Consensus reforms (greater transparency, more active competition policy, enhanced regulation, less focus on inflation, etc) would have on a world economy drifting dangerously towards depression and financial chaos. A new intellectual project-perhaps a 'post-Post-Washington Consensus' (e.g., from meetings of church/NGO/social movements in Lusaka and Nairobi in 1999, an 'Africa Consensus') - with respect to development, economics, ecology and global-local processes was sorely needed, and began emerging from diverse quarters.

66. Concrete manifestations include the Campaign Against Neoliberalism in South Africa (founded in 1996 upon a visit by Camdessus) and the SA Jubilee 2000 debt cancellation initiative, which had phenomenal success in 1998-99, publicising not only the $\$ 20+$ billion apartheid-era foreign debt but expanding the country's regional consciousness with respect to the $\$ 50$ billion "apartheid-caused debt" and destabilisation costs faced by the rest of Southern Africa. Finance ministry bureaucrats were forced onto the defensive about apartheid-debt repayment while social programmes were cut to the bone. In addition, along with left-leaning chapters in Nicaragua, Argentina and Philippines, the Southern African J2000 helped intensify pressure on G-7 leaders in mid-1999, at a time when cutting a highly-conditioned debtrelief deal appeared seductive to northern J2000 leaders and CoNGOs.

67. Peter Galli, 'Investors Wary of ANC Two-Thirds,' Jobannesburg Star Business Report, 5 June 1999. Corporate pressure on the ANC at the time South Africa's interim and final Constitutions were being drafted included not just property rights but a variety of other fundamental Bill of Rights protections (equivalent to those of natural persons, such as freedom of speech which made it impossible to regulate tobacco company advertising), protection from being taxed at provincial level, and an independent Reserve Bank. Yet contrary to Mobius' implication, none of these were in question in the 1999 campaign.

68. Samir Amin, 'Preface,' in A. Mahjoub (Ed), Adjustment or Delinking? The African Experience, London, Zed Press, 1990, pp.xii-xiii. See also his Delinking, London, Zed Press, 1990.

69. Alternative national- and regional-scale development policies have been established in several places, including the UN Economic Commission on Africa's AAF. SAP and the 1994 African National Congress Reconstruction and Development Programme (as well as other South African economic strategies offered by the Macroeconomic Research Group in 1993 and the Congress of South African Trade Unions in 1996). Such broad development policies should, naturally, follow directly from programmatic and project work being carried out by progressives in the field, because virtually all non-reformist reforms will run into strong opposition from economic policy-makers who are excessively committed to fiscal discipline, deregulating labour markets and 
promoting exports at all costs, and thus grassroots ownership of alternative strategies is vital to assuring they have popular durability under Washington Consensus duress.

70. Sam Ginden, 'Rising from the Ashes: Labour in the Age of Global Capitalism,' Montbly Review, 49, 3, July-August 1997, p.156, cited in Moody, Workers in a Lean World, p.308.

71. Michael Lowy, 'Globalization and Internationalism: How Up-to-date is the Communist Manifesto?,' Montbly Review, November 1998, pp.25-26. 